\title{
Criteria affecting Taiwan wealth management banks in serving high-net-worth individuals during COVID-19: a DEMATEL approach
}

\author{
Arthur J. Lin ${ }^{1} \cdot$ Hai-Yen Chang ${ }^{2} \cdot$ Sun-Weng Huang ${ }^{3,4} \cdot$ Gwo-Hshiung Tzeng ${ }^{4}$ \\ Received: 25 January 2021 / Revised: 1 April 2021 / Accepted: 27 May 2021 / Published online: 4 June 2021 \\ (c) The Author(s), under exclusive licence to Springer Nature Limited 2021
}

\begin{abstract}
Wealth management services for high-net-worth individuals in Taiwan have grown rapidly over the last decade. This study used a decision-making trial and evaluation laboratory approach to identify the criteria affecting the performance of Taiwan wealth management banks during the coronavirus disease (COVID-19) period. This research surveyed 17 executives from Taiwanese banks using 13 criteria covering three dimensions: bank performance, professionalism, and customer relationship. The results indicated that customer relationship and professionalism have an influence on key performance. Customer involvement (in customer relationship), innovative products and services (in professionalism), and customer satisfaction (in key performance) are the most influential criteria. The results suggest that banks can attract and retain customers by increasing their uses of products and services, developing innovative products, and improving customer satisfaction despite the negative effect of COVID-19. The findings of this study benefit wealth management bank managers in sustaining fee and commission income from high-net-worth customers in the midst of adverse social and economic events.
\end{abstract}

Keywords Wealth management $\cdot$ High-net-worth individual $\cdot$ Decision-making trial and evaluation laboratory (DEMATEL) $\cdot$ Fee and commission income $\cdot$ Asset under management (AUM) $\cdot$ COVID-19

Mathematics Subject Classification $\mathrm{C} 44 \cdot \mathrm{G} 01 \cdot \mathrm{G} 21 \cdot \mathrm{G} 22 \cdot \mathrm{N} 25$

Hai-Yen Chang

irischang1014@gmail.com; zhy3@ulive.pccu.edu.tw

Arthur J. Lin

arthurhagnes@gmail.com

Sun-Weng Huang

t107379004@ntut.org.tw

Gwo-Hshiung Tzeng

ghtzeng@gm.ntpu.edu.tw

1 Graduate Institute of International Business, National Taipei University, New Taipei City 237303, Taiwan

2 Department of Banking and Finance, Chinese Culture University, New Taipei City 11114, Taiwan

3 Department of Industrial Engineering and Management, National Taipei University of Technology, New Taipei City, Taiwan

4 Graduate Institute of Urban Planning, College of Public Affairs, National Taipei University, New Taipei City 237303, Taiwan

\section{Introduction}

Wealth management is defined as a financial service that combines asset allocation, portfolio management, financial planning, estate planning, and tax consulting for high-networth individuals and families (Beaverstock et al. 2013; Jennings et al. 2011; Ugolini 2018). Banks customize wealth management services to meet the needs of these individuals, whose combined balances from deposits, loans, and investments exceed a pre-determined amount set by the banks. Banks classify high-net-worth individuals into different levels based on their balances and provide varying degrees of special services (Jennings et al. 2011; Santacruz 2018).

Since the 2008 financial crisis, which led to higher loan defaults, banks throughout the world have modified their banking activities to increase the income from non-traditional fees and commissions (Park et al. 2019; Vozková 2018). Fee and commission income provide a sustainable source of income and lower the overall bank risk, which mainly comes from the traditional loan business (Abedifar et al. 2018; Vozková 2018). High-net-worth individuals 
contribute greatly to the fee and commission income earned by financial institutions; therefore, investment and commercial banks compete to attract and maintain affluent customers through various means, including personalized services, the provision of relevant information, and digital communication channels (Beaverstock et al. 2013; Santacruz 2018).

In addition, banks categorize the wealth of individuals by their liquid and investable assets, excluding real estate and rare collections (Beaverstock et al. 2013; Guido et al. 2020). Banks do not necessarily emphasize customers' income. This classification reflects the banks' strategy of increasing fee and commission income, which represents the largest portion of their non-interest income (Vozková 2018). Therefore, bank managers regard high-net-worth individuals as the primary source of non-interest income due to their abilities to invest in stocks, bonds, or mutual funds, thereby producing low-risk fee and commission income for banks (Beaverstock et al. 2013; Ting 2017; Vozková 2018).

Taiwan has seen rapid growth in wealth management over the last decade. Taiwan's domestic banks have accelerated the development of the wealth management segment due to their desire to capture wealthy people's money, which is usually invested in Singapore, Hong Kong, or other offshore locations (Santacruz 2018). According to a report by Taiwan Business Weekly (2018), total global wealth reached US\$280 trillion in 2017 and had an annual growth rate of $6.4 \%$. In comparison, the total wealth in Taiwan amounted to US $\$ 3.6$ trillion and reached an annual growth rate of $12.1 \%$, almost doubling the global average. Moreover, the total wealth in Taiwan is expected to grow by $5 \%$ per year continually until 2022 (Business Weekly 2018). Given such anticipated growth, Taiwanese financial holding companies have begun to develop wealth management services to attract the growing financial elite group.

The banks in Taiwan normally divide their services for the high-net-worth individuals into several tiers based on their assets. For example, two Taiwanese banks that received the 2018 top wealth management award by a popular Taiwanese business magazine, Wealth Magazine (2020), classify their Taiwan wealth management customers into three categories. The highest level (diamond) customers must maintain a minimum of US\$1 million at that bank, while mid- and second-level (platinum) customers must maintain a minimum of US $\$ 300,000$. The lowest-level customers must hold a minimum of $\$ 100,000$. According to Wealth Magazine (2020), 44\% of wealth management customers in Taiwan favor stock investments, and $40 \%$ are between the age of 35 and 45 . Regarding family responsibilities, these customers seek to manage their parents' wealth for retirement and pass on the wealth to their children simultaneously. Moreover, $91 \%$ of wealth management customers have used digitalized services such as internet banking and mobile applications.
The competition among the Taiwanese banks for wealth management has intensified due to the high growth potential. However, asset management in unfavorable financial markets seems to be a challenge. Chang and Tsai (2016) found that the 2008 financial crisis produced a disruptive effect on individual wealth and bank performance because the banks offered their high-net-worth customers stock trading, structured investments, and mutual fund services. Hence, Chang and Tsai (2016) concluded that creating value for affluent customers during financial turbulence is essential for bank sustainability. Prior researchers studied the success factors of wealth management banks and found that financial performance, service quality, consumer confidence, and professionalism were critical (Chan and Chan 2011; Chang and Tsai 2016; Gunardi et al. 2020; Ting 2017; Yeh 2015).

A worse global event affecting developed and emerging financial markets after 2008 is the coronavirus disease (COVID-19) pandemic that began in December 2019. In March 2020, global stock markets declined by 25\%-30\%, and there was widespread fear among investors. On March 9, 2020, the Dow Jones Industrial Average (DJIA) fell by more than 2000 points, representing a $7.79 \%$ drop in one day. On March 12, 2020, the DJIA further plunged by $9.99 \%$, which was the largest one-day drop in DJIA's history since Black Monday in 1987. Similarly, the Taiwan stock market was severely affected by the COVID-19 pandemic. The Taiwan stock market-weighted index fell from 12,179 points on January 14, 2020, to a low of 8681 points on March 19, 2020 , representing the largest fall of $40 \%$ in the stock index since the 2008 global financial crisis.

As a result of COVID-19, investors saw a direct impact on their portfolios, and wealth management banks experienced a drop in the fee and commission income tied to investment transactions (McKinsey 2020). Although understanding the key success factors affecting wealth management bank services is important, the extant literature studied banks following the 2008 global financial crisis. Scant research has discussed the ways in which banks responded to their highnet-worth customers who may be affected the most during the recent turbulent period of the COVID-19 pandemic in 2020.

The purpose of this study was to identify the most important criteria affecting wealth management banks during the 2020 COVID-19 pandemic using the decision-making trial and evaluation laboratory (DEMATEL) technique in the multiple-criteria decision-making (MCDM) model. The DEMATEL technique, proposed by Fontela and Gabus (1976), can find the interrelationships among the selected criteria in a particular system. We obtained expert opinions from seventeen (17) executives from five top wealth management banks in the Taiwan banking industry. This study evaluated wealth management banking services from three 
dimensions (key performance, professionalism, customer relationship) and 13 criteria.

The results of this study indicated that customer relationship is the greater cause, followed by professionalism, while key performance is the effect. Customer involvement, innovative products and services, and customer satisfaction are the most influential criteria within the three dimensions. Overall, COVID-19 has altered the ways in which wealth management banks serve their customers. The results of this study suggest bank managers focus on increasing customer use of products and services and emphasizing the benefits of switching to their banks. Moreover, banks may develop innovative products and services such as robot-advisors, online and mobile banking, or timely information updates through short messages, during times in which contactless service is preferred (Ananda et al. 2020). Furthermore, banks can enhance customer satisfaction by providing personalized services such as tailored investment portfolios and estate planning. As a result, banks could increase the number of customers, fee income, and commission income. The findings of this study could benefit banks in designing their wealth management programs to serve high-net-worth individuals and families during the COVID-19 pandemic.

This study contributes to the literature in three ways. First, this paper is the first to investigate the criteria affecting wealth management banks during the COVID-19 period. Second, this research includes many new criteria, such as fee income and cost of switching, which are related specifically to the banking industry. Third, we apply the DEMATEL method to analyze the opinions of wealth management banks regarding the interaction between customers and financial institutions, thus providing practical recommendations for bank managers when human interaction is minimized. The results of this study are helpful to wealth management banks in sustaining their businesses during the turbulent period.

The rest of this paper is organized in the following order. Section "Literature review" describes the extant literature. Section "Method" provides the research method. Section "Results" presents the results, implications, and discussion. Section "Discussion and managerial implications" includes a discussion and managerial implications. Section "Conclusions, limitations, and future research" concludes the paper.

\section{Literature review}

A large body of literature has discussed the factors influencing bank performance evaluation. The most common criteria to evaluate bank performance are business performance and customer perspectives (Chang and Tsai 2016; Ting 2017; Wu et al. 2010).

\section{Key performance}

Key business performance is an essential decision criterion in the selection of banks because it induces consumer confidence (Chang and Tsai 2016).

\section{Customer information file}

Previous studies have suggested that banks keep customer information files (CIFs), which are an electronic file that contains information about a customer's personal and account information to understand customer behavior and practice customer relationship management (Haenlein et al. 2007; Verhoef and Donkers 2001). Banks can create strategies to realize the potential value of a particular customer based on the CIF (Verhoef and Donkers 2001).

\section{Assets under management}

Vanini (2020) described assets under management (AUM) as the market value of the assets managed by a financial institution for its customers. AUM is a key measurement for the success of a financial institution. A growing AUM means that customers have higher confidence in the financial institution managing the funds.

Investment banks commonly use AUM to measure their abilities to generate higher returns for investors (Jennings et al. 2011; Vanini 2020).

\section{Fee income}

Doumpos et al. (2016) studied banks worldwide and concluded that diversification from interest to non-interest income benefits banks financially in both developed and emerging markets. Vozková (2018) examined 258 European banks from 2014 to 2017 and found that banks facing higher market competition expanded more actively into non-traditional fee income from services. Yin and Matthews (2018) investigated 2000 banks from 1999 to 2012 and found that the strong financial conditions of financial institutions attract more firms or individuals. The results revealed that banks earning fee income are more effective in locking in their current customers (Yin and Matthews 2018). These studies found that customers have a lower tendency to switch to other banks if the current banks offer a bundle of financial services, such as loans and mutual funds (Vozková 2018; Yin and Matthews 2018).

\section{Commission income}

Hackethal et al. (2012) discovered that individuals purchase insurance from financial advisors to diversify risks. Thus, advisors at financial institutions promote insurance policies 
for insurance companies to provide customers with financial protection or reimbursements against losses. However, Nisar et al. (2018) examined 200 commercial banks from South Asian countries and found that commission income is negatively related to the profitability of these banks because the cross-selling of fees, commissions, and interest-bearing products to the same customers reduce banks' commission income from selling insurance policies.

\section{Customer satisfaction}

Tadic et al. (2018) argued that customer service quality is the primary measure of customer satisfaction for banks facing the fierce competition of the financial sector. Grigoroudis et al. (2012) emphasized the significantly positive correlation between customer satisfaction and customer loyalty in Greece. Previous studies have indicated that the long-term success of a bank depends on customer satisfaction, which represents a bank's ability to fulfill changing customer needs and preferences (Grigoroudis et al. 2012; Mihelis et al. 2001; Shaverdi et al. 2011; Ting 2017). Mihelis et al. (2011) and Ting (2017) found that customer satisfaction stems from personnel (attitude, knowledge and skills), products (variety, cost), bank image (creditability, technological advancement), and services (convenience, adequate, and timely information).

\section{Professionalism}

Previous studies defined the professionalism of a bank as its innovative capacity, new product development, and integration of technologies and customer data (Chang and Tsai 2016; Ting 2017). Chang and Tsai (2016) used a hybrid model to evaluate the performance of seven Taiwan wealth management banks affected by the 2008 global financial crisis. The results indicated that the best wealth management bank had the highest score for service and professionalism, resulting in the highest fee and commission income. Ting (2017) argued that the professionalism of financial advisors significantly influences customers' decisions to establish a relationship with a particular bank.

\section{Innovative products and services}

Wu et al. (2010) analyzed the performance of four wealth management banks in Taiwan and found that a successful bank provides innovative services, such as the digitalization of business processes. Phoon and Koh (2018) argued that disruptive technology, particularly financial technology (FinTech), and mobile banking greatly influence the success of banks. Prior studies have indicated that the innovative developments of robot-advisors could improve returns on asset allocation and portfolio monitoring (Phoon and Koh 2018; Semko 2019; Yeh 2017).

\section{Comprehensive investment information}

Ting (2017) stated that the comprehensive financial services provided by wealth management banks are essential to highnet-worth individuals because these customers own a large amount of assets and seek long-term growth of their wealth in many areas. Prior research has unveiled that wealth management banks may distinguish themselves by their abilities to provide comprehensive yet customized solutions to their multiple investment goals, such as offshore investments, family portfolio management, and life annuities (Benoit et al. 2012; Jennings et al. 2011; Mihelis et al. 2001; Wu et al. 2010). Komulainen and Makkonen (2018) emphasized that the utilization of various channels in delivering banking services greatly enhances customer experience.

\section{Family financial planning}

Prior researchers have explained that one of the focuses of wealth management shifted after the 2008 financial crisis to become family oriented. These authors discovered that asset allocation for wealthy individuals covers a range of family financial planning activities, including asset allocation, estate planning, philanthropic planning, and trusts (Ananth et al. 2010; Ang 2010; Beaverstock et al. 2013; Brunel 2011; Santacruz 2018). Jennings et al. (2011) divided wealthy individuals into three groups: mass affluent (US\$1 million), high-net-worth (US\$50 million), and ultra-highnet-worth (US\$100 million) individuals, and found that all three groups have the needs of estate planning to transfer wealth to the next generation.

\section{Customer relationship}

Previous studies have evaluated bank performance from customers' perspectives (Ananth et al. 2010; Benoitand Van den Poel 2012; Stankevičiené and Mencaitè 2012; Wu et al. 2010). These studies emphasized customer relationship management (CRM) to increase customer loyalty. These banks create separate offices, services, and additional benefits to attract and retain high-net-worth customers, expecting to generate more profits from these customers than regular retail banking customers (Ananth et al. 2010; Benoit and Van den Poel 2012).

\section{Customer involvement}

Ananth et al. (2010) surveyed 200 private banking clients in Iran and found the key to deepening bank relationships with customers is to increase the usage of bank services by 
cross-selling financial products. Moreover, previous studies have revealed that banks may retain their most profitable customers by offering loyalty programs to increase customer involvement, which refers to selling more products and services to customers (Benoit and Van del Poel 2012; Haenlein et al. 2007). Such practices are particularly useful for family networks (Benoit and Van del Poel 2012).

\section{Relationship bond}

Milan et al. (2018) studied Brazilian banks and found that building a long-term bond between banks and customers may reinforce mutual trust. These authors also expounded that strong financial bonds with customers can significantly increase customer loyalty to the banks. Geiger et al. (2012) investigated the relationship bonding effect on the values of firms in Germany, Korea, and New Zealand and revealed that sellers strengthen their ties with buyers through frequent communication and by meeting customers' specific needs.

\section{Benefit of switching}

Hsu (2014) defined the switching benefit as the perceived value a user receives in switching from the current to a new service provider. The switching benefit is typically viewed as an increase in outcome and a decrease in inputs. Hsu (2014) found that when customers can receive more benefits from other banks, they will have a stronger intention to switch. Van der Cruijsen and Diepstraten (2017) investigated bank switching behavior using 2194 European consumers. The results showed that customers decide to stay with their current banks mainly due to having a good bank-customer relationship and low benefits in switching. On the contrary, a bank may attract customers from other banks by offering more benefits, such as discounts, lower service charges, and higher deposit interest rates (Van der Cruijsen and Diepstraten 2017).

\section{Cost of switching}

Blut et al. (2016) defined the switching cost as customers' perception of the additional costs required to terminate the relationship with the current service provider. Therefore, managers design their services to increase switching costs through offering special discounts or unique customer solutions. Zhao et al. (2013) compared British banks in terms of switching costs between 1993 and 2008. The results indicated that banks can increase the costs of their customers switching to other banks and lock in their customers by engaging them in a wider range of products. Prior researchers have also discovered that customers' perception of switching costs rise when they deepen their involvements at a particular bank. These customers tend to develop high resistance to change (Barroso and Picon 2012; Zhao et al. 2013).

\section{Switching behavior}

Yin and Matthews (2018) analyzed banks in China from 1999 to 2012 to examine what factors drive firms' switching from one bank to another. The results suggested that banks that develop fee-income services are more effective in retaining their customers. Mutum et al. (2014) related customers' switching behavior to their perceived switching costs, such as the uncertainty cost, loss of the relationship bond, time and effort cost, search cost, learning cost, and the set-up cost. Prior studies have suggested that customers will turn their switching intention into switching behavior when the benefits of switching exceed the costs of switching to other banks (Hsu 2014; Mutum et al. 2014).

\section{COVID-19}

COVID-19 is a contagious disease caused by a new coronavirus that is responsible for an outbreak of respiratory illness that began in China in December 2019 (Ocampo and Yamagishi 2020). COVID-19 spreads from one person to another through close physical contact (CDC 2020). The outbreak of this disease rapidly spread across the world, with many governments imposing lockdown measures for the economy and society. As of July 26, 2020, the total number of confirmed cases worldwide was 15,745,102 and the number of deaths was 639,317 . The world mortality rate is $4.06 \%$ (World Health Organization 2020). As of July 26, 2020, the top nations with the highest mortality rates were Italy, Spain, Sweden, Iran, Germany, Brazil, and the USA (CDC 2020).

Previous studies stated that a wide-spread global event can change the ways in which banks provide financial services to customers (Chang and Tsai 2016; Phoon and Koh 2018). The 2008 global financial crisis had a substantial negative impact on stock markets and caused banks to become increasingly cautious about their investments (Schroder 2013; Ugolini 2018). The biggest challenge faced by banks in 2019-2020 is COVID-19, which caused global stock markets to plunge by 20 to $30 \%$ during March 2020. Given the impact of COVID-19 during 2019 and 2020, wealth management banks are likely to alter their practices in serving high-net-worth customers, in the hopes of recovering from financial losses. COVID-19 has affected both investors and wealth management providers. Wealth management banks experienced a decline in their AUM and the associated fee income due to weakening markets and high volatility (Deloitte 2020; McKinsey 2020). COVID-19 has had a significant impact on wealth management banks because these banks attempt to respond to their customers' needs in an adverse market situation (McKinsey 2020). 
Taiwan saw its first COVID-19 case on January 21, 2020, and reported 307 confirmed cases on April 6, 2020. The Taiwan Centers for Disease Control reported 1,050 confirmed cases and 10 deaths as of April 8, 2021. The relatively low number of confirmed cases in Taiwan was mainly due to the early restrictions placed by the government in the first quarter of 2020. In December 2019, the Taiwan officials realized the origin of the virus in China and halted the flights from most regions in China in January 2020. Starting from March 19,2020 , all foreign visitors were prohibited from entering Taiwan except those with resident certificates or work permits. The Taiwan government required those passengers who were admitted into Taiwan to quarantine for 14 days upon the arrival (Taiwan CDC 2020).

In May 2020, the Taiwan government downgraded its forecast for the Taiwan gross domestic product (GDP) growth in 2020 to $1.15 \%$ from $2.58 \%$ projected in December 2019, due to the economic impact of the COVID-19. Stagnant export demand and weak domestic consumption undermined the Taiwan economy. The consumer spending for the first quarter of 2020 saw a negative growth of $4.98 \%$, which was the highest drop in Taiwan history (Focus Taiwan 2020).

Moreover, the COVID-19 outbreak severely affected the Taiwan stock market in early 2020. The Taiwan stock market-weighted index fell from 12,179 points on January 14, 2020, to 8,681 points on March 19, 2020, representing the worst drop of $40 \%$ in the stock index since the 2008 global financial crisis. According to Lee and Lu (2021), adverse economic events lower the value of stocks, causing the psychological and behavioral responses of the investors to further withdraw from risky investments. Thus, the highnet-worth customers who held relatively large risky investment portfolios experienced greater shrinkage in asset values (Lee and Lu, 2021).

Based on the literature review above, we identified three dimensions: key performance $\left(D_{1}\right)$, professionalism $\left(D_{2}\right)$, and customer relationship $\left(D_{3}\right)$. In addition, we selected 13 criteria $\left(C_{1}\right.$ to $\left.C_{13}\right)$ under the three dimensions to determine their cause-and-effect relationships during the COVID-19 pandemic. The descriptions of the criteria are included in Table 1.

\section{Comparison between the extant literature and current method}

The extant literature investigated the factors affecting the performance of wealth management banks in the emerging countries such as Taiwan and Indonesia. The common methods found in the literature included survey questionnaires collected from field experts, the analytical hierarchy process (AHP), and the structural equation model (SEM). In the early years of 2010 and 2011, the researchers attempted to build models to assess the performance of wealth management banks. Then, the scholars incorporated corporate responsibility, risk control, and consumer confidence to examine banks after the 2008 global financial crisis. The studies after 2017 stressed bank competitiveness, product,

Table 1 Dimensions and criteria for the evaluation of wealth management banks

\begin{tabular}{|c|c|c|}
\hline Evaluation dimension & Evaluation criteria & Description \\
\hline \multirow[t]{5}{*}{$D_{1}$ Key performance } & $C_{1}$ Customer information file (CIF) & $\begin{array}{l}\text { An electronic file that stores the information about a customer's personal } \\
\text { and account information }\end{array}$ \\
\hline & $C_{2}$ Assets under management (AUM) & $\begin{array}{l}\text { The total market value of the assets managed by a financial institution on } \\
\text { behalf of its customers }\end{array}$ \\
\hline & $C_{3}$ Fee income & Bank charges from services \\
\hline & $C_{4}$ Commission income & Commission earned by a bank for selling an insurance policy \\
\hline & $C_{5}$ Customer satisfaction & $\begin{array}{l}\text { Measure of how pleased customers are with the products and services } \\
\text { offered by banks }\end{array}$ \\
\hline \multirow[t]{3}{*}{$D_{2}$ Professionalism } & $C_{6}$ Innovative products and services & New, redesigned, or substantially improved financial tools and services \\
\hline & $C_{7}$ Comprehensive investment information & A full range of financial market information and investment strategies \\
\hline & $C_{8}$ Family-based financial planning & $\begin{array}{l}\text { Financial planning involving the goals, resources, and responsibilities of } \\
\text { the entire family }\end{array}$ \\
\hline \multirow[t]{5}{*}{$D_{3}$ Customer relationship } & $C_{9}$ Customer involvement & The number of products purchased and services used by customers \\
\hline & $C_{10}$ Relationship bond & Connections and positive experiences that unite banks and customers \\
\hline & $C_{11}$ Benefit of switching & $\begin{array}{l}\text { Perceived value a customer receives in switching from the current to a } \\
\text { new bank }\end{array}$ \\
\hline & $C_{12}$ Cost of switching & $\begin{array}{l}\text { Perceived costs a customer pays to terminate the relationship with the } \\
\text { current bank }\end{array}$ \\
\hline & $C_{13}$ Switching behavior & $\begin{array}{l}\text { The level of propensity of a customer to turn switching intention to } \\
\text { switching behavior }\end{array}$ \\
\hline
\end{tabular}


and service. Prior research works related to wealth management banks are described in the following.

Wu et al. $(2010,2011)$ first established a model integrating balanced score (financial, customer, internal process, learning, and growth), AHP, and grey relational analysis (GRA) to evaluate the performance of four large wealth management banks in Taiwan. The AHP technique computes the weight of each perspective. These authors unveiled that the financial and customer perspectives were most important. Chan and Chan (2011) built a predictive model using surveys developed based on the theory of planned behavior to determine the intentions of the Taiwanese citizens residing in China in choosing wealth management banks using ten factors. This study surveyed 227 Taiwanese citizens based in China and found that trustworthiness, flexible services, and cultural affinity were most crucial factors in selecting wealth management banks.

Yeh (2015) examined the relationship between corporate social responsibility (CSR), service innovation, and customer loyalty. This study surveyed 527 wealth management customers in Taiwan and analyzed the data using the SEM method which combines factor analysis and regression analysis. The results indicated that relationship quality and value were positively related to customer loyalty. Chang and Tsai (2016) constructed a model integrating AHP and VlseKriterijumska Optimizacija I Kompromisno Resenje (VIKOR) to evaluate the performance of wealth management banks after the 2008 global financial crisis. The VIKOR method measured the closeness to the ideal solution. This study surveyed 18 managers from seven wealth management banks in Taiwan using five criteria. The authors revealed that consumer confidence, risk control, and service remained most critical after the 2008 global turbulence.

Ting (2017) compared the financial advisors and investors' views regarding the criteria (image, product, quality of service) affecting wealth management banks using the AHP method. The author collected questionnaires from 111 financial advisors and 137 investors in Taiwan. The survey results showed a discrepancy between the investors and financial advisors. The financial advisors regarded the quality of service as the most important factor, while the investors preferred financial products. Gunardi et al. (2020) scrutinized the performance of private wealth management banks in Indonesia using the partial least square (PLS) model and SEM. This study surveyed 60 managers from 32 Indonesian banks to select among the criteria (competitiveness, risk management, private bank performance, growth of retail banking business). This study found the most important factors to be bank competitiveness and market share. In addition, the performance of wealth management significantly influenced the growth of retail banking in Indonesia. Table 2 summarizes the previous research work related to wealth management bank evaluation.
This study differs from the previous studies in three ways. First, previous studies used general criteria such as product and services (Chan and Chan 2011; Ting 2017; Wu et al. 2011; Yeh 2015); this current research adopted both quantitative (customer relationship and professionalism) and qualitative factors (key performance), as well as incorporating many bank-specific criteria such as CIF, AUM, and cost of switching. We also included fee and commission income, which became an important source of income for banks after the 2008 financial crisis. Given these industry-specific criteria, the study obtained precise responses from the experts regarding bank performance.

Second, this current study applied the DEMATEL method, which was developed by the Science and Human Affairs Program of the Battelle Memorial Institute of Geneva between 1972 and 1976 (Fontela and Gabus 1976). The DEMATEL method is part of the MCDM model. The DEMATEL technique has been applied to areas such as marketing strategies, control systems, and group decision-making processes (Peng and Tzeng 2013). Unlike AHP, VIKOR, and SEM that treated each criterion as an independent factor without relationships with others, the DEMATEL method deals with complex social problems by locating the interdependence of the factors. The DEMATEL technique can discover the influential networks among qualitative criteria to identify the cause and effect among multiple criteria (Lee et al. 2013; Li and Tzeng 2009; Tzeng and Huang 2012). In practice, the DEMATEL technique can build a pairwise influential network relationship map (INRM) to identify the inter-relationships among pre-determined dimensions and criteria. Furthermore, the DEMATEL technique can detect the degree of influence for each criterion on others (Lee et al. 2013).

Third, prior studies focused mostly on the bank performance after the 2008 crisis and during a tranquil period from 2010 to 2017. Previous researchers examined the wealth management banks with rapid growth without facing a major crisis in the financial markets. This paper investigated the bank practices which during the difficult time of the COVID19 outbreak, which has caused the largest fall in the stock market since the 2008 global crisis. This study identifies the factors (causes) for the banks to be sustainable during the adverse period and indicates the effects if banks implement these practices.

\section{Method}

The evaluation framework of this study consisted of four steps. This study applied the Delphi method proposed by Murry and Hammons (1995) to include expert opinions on the most influential criteria. The first step was to identify multiple criteria based on the literature so that the bank 


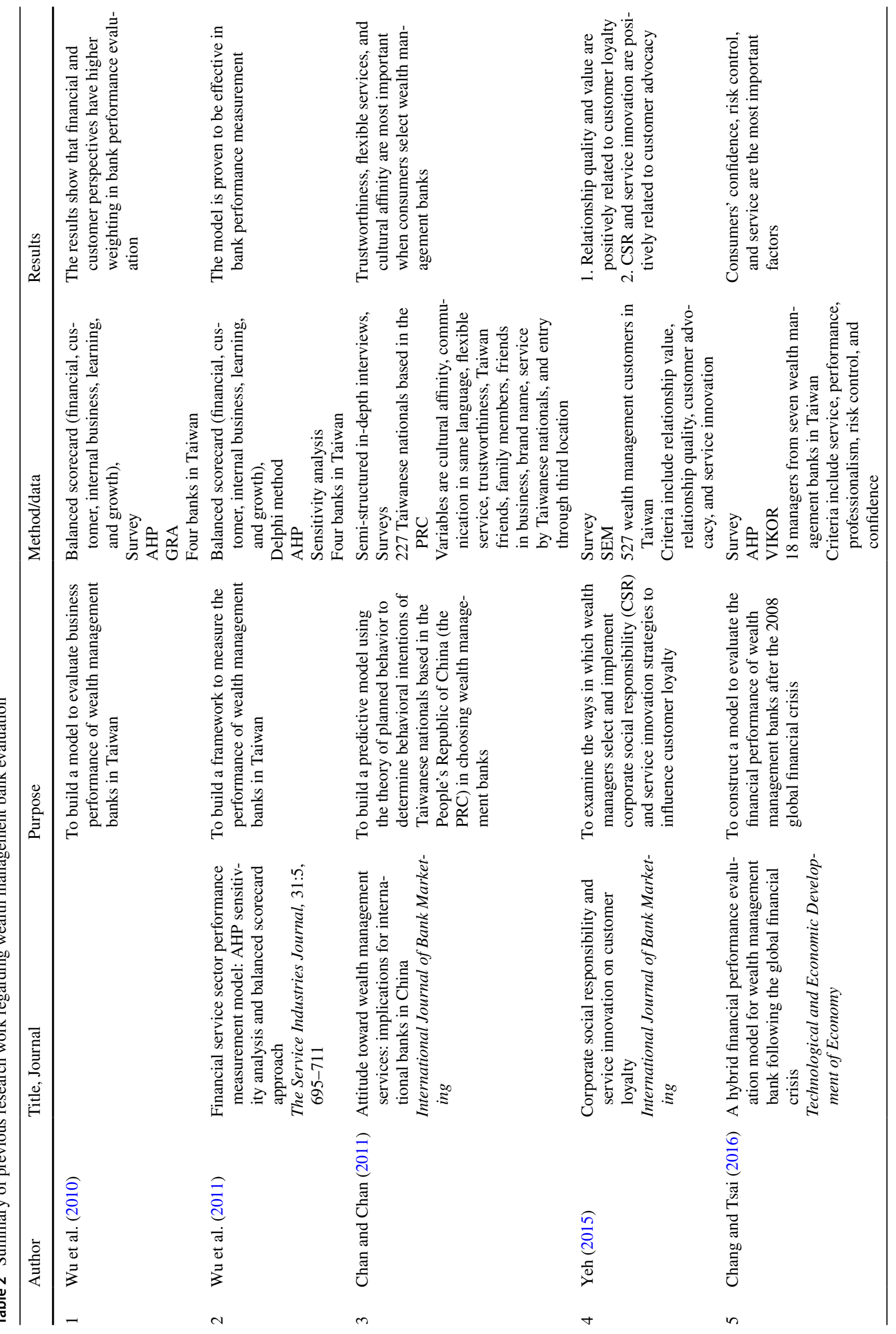




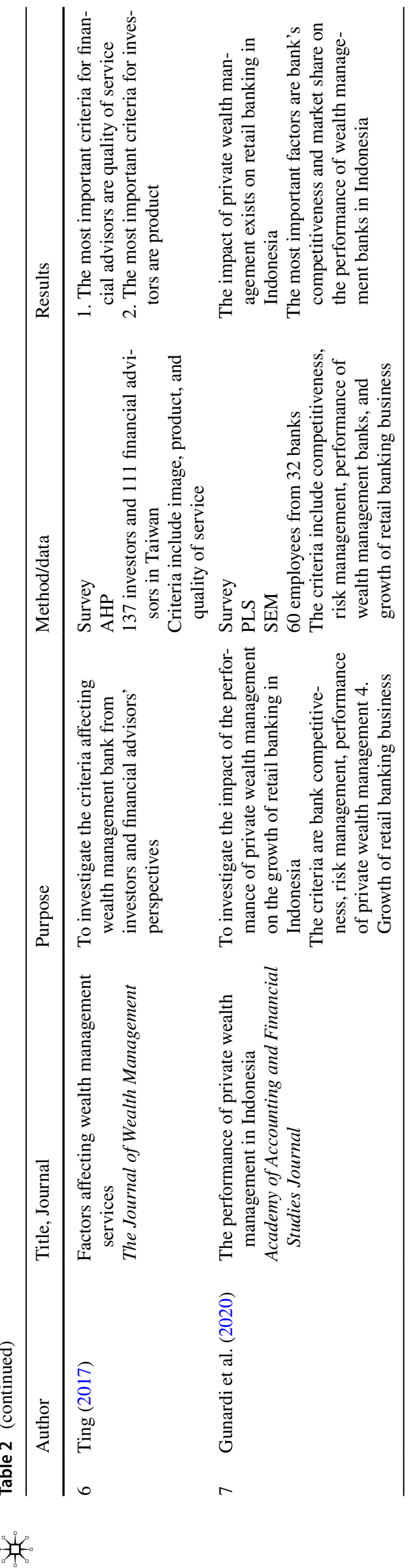

experts could evaluate the influence of each criterion. The second step was to prepare a survey based on the 13 criteria for 17 Taiwanese bank executives from five large wealth management banks to identify the relationships among the dimensions and criteria. The executives provided pairwise comparisons between any two criteria expressed as a score from 0 to 4 . A score of (0) indicated no influence, while (1) indicated low influence, (2) indicated medium influence, (3) indicated high influence, and (4) indicated extremely high influence. The third step was to apply the DEMATEL technique to identify the influential networks among the criteria related to wealth management. The fourth and last step was to determine the most influential criteria and discuss the implications. The evaluation framework for wealth management bank performance is depicted in Fig. 1.

The Delphi method analyzes the opinions of anonymous experts that communicate in written, discussion, and feedback formats on a particular topic (Steward et al. 1999). Following the approach by Chang and Tsai (2016), we first selected 17 anonymous experts and then conducted the questionnaire survey based on the 13 selected criteria. All the experts had over ten years of experiences in the banking industry.

\section{Bank selection}

Taiwan has 34 domestic banks and 24 foreign banks. Out of the total 58 banks, 12 banks provide wealth management services. Starting 2007, Business Today Weekly, a leading weekly business magazine, and the private Shih Hsin University have jointly bestowed the Wealth Management Banking and Securities Award to the Taiwan banks each year. Business Today Weekly invited experts to evaluate the Taiwan wealth management banks based on 12 categories such as product, financial consultant team, asset value increase, customer satisfaction, trust, image, risk management, digital tools, and sustainability (Business Today 2020). Another prominent Taiwanese business magazine, Wealth Magazine, also evaluated the wealth management banks in Taiwan in the last decade. This study selected the top five banks that received the awards from the two magazines during 2017-2019. The following section briefly describes the five winner banks.

a. Bank A (C. U. Bank) was established in 1975. Bank A belongs to the largest Taiwanese financial holding company that owns an insurance and security firm. This holding company was ranked second in profitability and received the best performance award during in 2020 . Bank $A$ received the top three wealth management award for three consecutive years from both Business Today Weekly and Wealth Magazine. Bank A was also the winner in the category of bank image, customer sat- 
Fig. 1 Evaluation framework for wealth management bank performance

\section{Step 1: Select the criteria for \\ evaluating wealth management bank performance \\ based on literature review}

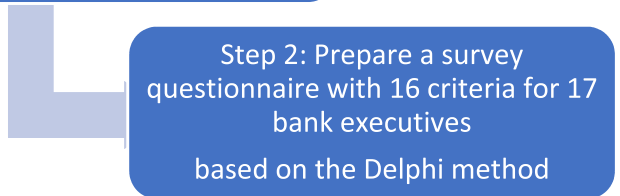

isfaction, and sustainability. Bank $\mathrm{A}$ is the second largest bank in Taiwan based on the asset size of US\$109,628. It owns 236 branches and 11 overseas branches. This bank offers a wide range of consumer banking products and is recognized for alerting their customers at the start of the COVID-19 to shift their investments to lower the overall portfolio risks.

b. Bank B (C. T. Bank) was established in 1966. Bank B belongs to the third-large financial holding company in Taiwan. Bank B received the top three wealth management for three consecutive years from 2017 to 2019 . The financial holding company that owns Bank B ranked third in profitability in 2020. Bank B was also the winner in the two categories of the best financial consultant team and digital tools. Bank B is the largest bank in Taiwan in terms of asset size of US\$127,120 million. It is regarded the most internationalized Taiwanese bank with 152 domestic branches and 116 overseas branches. This bank initiated the wealth management programs for business owners and the financial and estate planning package for the entire family up to three generations.

c. Bank C (E. S. Bank) was established in 1992 and owned by its financial holding company that ranked fourth in the financial holding company award. Bank C has 139 branches and 28 overseas branches. Bank $\mathrm{C}$ received the best wealth management bank by Business Today Weekly and Wealth Magazine in 2019. In addition, Bank $\mathrm{C}$ was the winner in the two categories of financial consultant team and increase in asset value in 2019. Bank C has an asset size of US\$90,665 million and is renowned for providing overseas banking products such as foreign bonds, US stocks, and global ETF. d. Bank D (F. B. Bank) was established in 1992 and is owned by the second-largest financial holding company in Taiwan. Bank D received the highest score on customer satisfaction by Business Today Weekly in 2019 . This financial holding company ranked first in profitability from 2017 to 2020 and was listed in the Fortune Global 500. Bank D is the third largest bank in Taiwan based on the asset size of US\$95,075 million. It owns 135 domestic and 6 overseas branches. It offers an extensive product line covering corporate and consumer banking and insurance products. It excels in cross-selling its bank products to its large number of insurance customers. It is also the first bank to establish an offshore office in Hong Kong.

e. Bank E (T. S. Bank) was established in 1992 under the financial holding company. Bank E received best wealth management bank award from the Wealth Magazine from 2017 to 2019 (Wealth Magazine 2020) and the Excellence award from the Business Today Weekly. Bank E has an asset size of US70,090 million and 100 domestic and four overseas branches. It is known for its financial innovation and the ability to identify customer needs using big data. It was one of the pioneer banks in developing a digital platform to communicate with and serve customers online.

\section{Data}

This study distributed survey questionnaires forms with three dimensions and 13 evaluation criteria for wealth management banks to 17 anonymous executives from five large Taiwanese banks. The executives consisted of seven 
male and ten female bankers with an average age of around 50. Eleven of the bank executives had more than 20 years of work experiences, and six had over 15 years of work experiences.

The 17 executives were asked to assess the direct influence between each pair of criteria based on a score of 0 to 4. In addition, the 17 executives were requested to write their opinions on the forms to provide additional information about the bank practices used to cope with challenges arising from COVID-19 (Torbacki and Kijewska 2019). All 17 executives completely answered the survey questions and returned them independently to the researchers.

\section{DEMATEL model}

We analyzed the results of the survey questionnaires based on the DEMATEL technique, which consists of five steps (Maqbool and Khan 2020; Qarnain et al. 2020), as shown in Fig. 2.

\section{Step 1: Generate initial influence matrix $\mathbf{R}$}

Based on the experts' opinions, the initial direct influencerelation matrix $\boldsymbol{R}$ can be constructed, where $r_{i j}$ denotes the influence of criteria $i$ on another criteria $j$ as perceived by the experts, as shown in Eq. (1):

$$
\boldsymbol{R}=\left[r_{i j}\right]=\left[\begin{array}{ccccc}
r_{11} & \cdots & r_{1 j} & \cdots & r_{1 n} \\
\vdots & & \vdots & & \vdots \\
r_{i 1} & \cdots & r_{i j} & \cdots & r_{i n} \\
\vdots & & \vdots & & \vdots \\
r_{n 1} & \cdots & r_{n j} & \cdots & r_{n n}
\end{array}\right]_{n \times n} .
$$

The average values obtained from the surveys are used to form average direct influence relation matrix $\boldsymbol{A}$, which indicates the level of influence of one criterion on another and of one criterion from others. Therefore, an $n$ column by $n$ row average matrix $\boldsymbol{A}$ can be built by Eq. (2), where $n$ equals the number of total criteria $(1 \leq i \leq n$ and $1 \leq j \leq n)$

$\boldsymbol{A}=\left[a_{i j}\right]=\left[\begin{array}{ccccc}a_{11} & \cdots & a_{1 j} & \cdots & a_{1 n} \\ \vdots & & \vdots & & \vdots \\ a_{i 1} & \cdots & a_{i j} & \cdots & a_{i n} \\ \vdots & & \vdots & & \vdots \\ a_{n 1} & \cdots & a_{n j} & \cdots & a_{n n}\end{array}\right]_{n \times n}$

\section{Step 2: Conduct a test of the expert's consensus deviation index (CDI)}

The CDI value obtained from Eq. (3), which represents the consensus degree of the experts, is used to conduct a test of the expert's consensus deviation index (CDI). In this paper, the CDI threshold was set at 5\% (Lin et al. 2019; Qu et al. 2019). A threshold less than 5\% would indicate that the confidence level was higher than $95 \%$ and that the system was stable. On the contrary, if an unstable system was found, the first stage of calculation would be reperformed to verify the accuracy of data collection and adequacy of experts.

$$
C D I=\frac{1}{n(n-1)} \sum_{i=1}^{n} \sum_{j=1}^{n}\left(\left|d_{i j}^{H}-d_{i j}^{H-1}\right| / d_{i j}^{H}\right) \times 100 \% .
$$

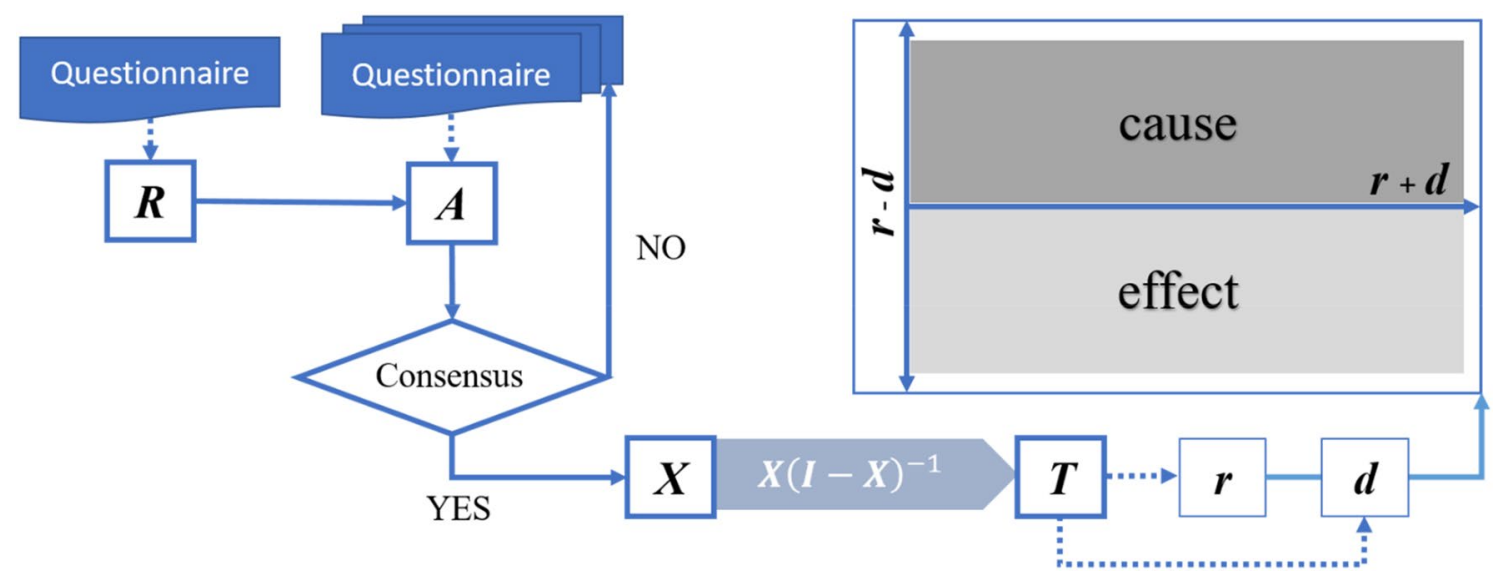

Fig. 2 Process of DEMATEL technique 


\section{Step 3: Obtain the normalized average direct influence} relation matrix $X$

Matrix $\boldsymbol{X}$ can be derived from Eqs. (4) and (5), where $m$ is a constant used for normalizing $\boldsymbol{X}$ :

$\boldsymbol{X}=m \boldsymbol{A}=\left[x_{i j}\right]=\left[\begin{array}{ccccc}x_{11} & \cdots & x_{1 j} & \cdots & x_{1 n} \\ \vdots & & \vdots & & \vdots \\ x_{i 1} & \cdots & x_{i j} & \cdots & x_{i n} \\ \vdots & & \vdots & & \vdots \\ x_{n 1} & \cdots & x_{n j} & \cdots & x_{n n}\end{array}\right]_{n \times n}$

$m=\min \left\{1 / \max _{i} \sum_{j=1}^{n} a_{i j}, 1 / \max _{j} \sum_{i=1}^{n} a_{i j}\right\}, i, j \in\{1,2, \ldots, n\}$.

\section{Step 4: Derive the total influence relation matrix $T$}

The indirect effects of the model diminish with an increase in the power of $X$. The total influence-relation matrix $\boldsymbol{T}$ is defined by Eqs. (6) and (7), in which $\boldsymbol{I}$ denotes the identity matrix:

$$
\begin{aligned}
\boldsymbol{T} & =\boldsymbol{X}+\boldsymbol{X}^{2}+\boldsymbol{X}^{3}+\cdots+\boldsymbol{X}^{k} \\
& =\boldsymbol{X}\left(\boldsymbol{I}+\boldsymbol{X}+\boldsymbol{X}^{2}+\cdots+\boldsymbol{X}^{k-1}\right)\left[(\boldsymbol{I}-\boldsymbol{X})(\boldsymbol{I}-\boldsymbol{X})^{-1}\right] \\
& =\boldsymbol{X}\left(\boldsymbol{I}-\boldsymbol{X}^{k}\right)(\boldsymbol{I}-\boldsymbol{X})^{-1} .
\end{aligned}
$$

Then,

$\boldsymbol{T}=\boldsymbol{X}(\boldsymbol{I}-\boldsymbol{X})^{-1}$, when $k \rightarrow \infty, \boldsymbol{X}^{k}=[0]_{n \times n}$

$\mathrm{w}$

$\mathrm{h}$

$\mathrm{e}$

$\mathrm{r}$

$\boldsymbol{T}=\left[t_{i j}\right]_{n \times n}, 0 \leq t_{i j}<1,0<\sum_{j=1}^{n} t_{i j} \leq 1,0<\sum_{i=1}^{n} t_{i j} \leq 1$.

If at least one row or column of summation is equal to 1 (but not all) in $\sum_{j=1}^{n} t_{i j}$ and $\sum_{i=1}^{n} t_{i j}$, then we can guarantee $\lim _{k \rightarrow \infty} X^{k}=[0]_{n \times n}$.

\section{Step 5: Generate the cause-effect relation map}

The sum of each column and row in $T$ are analyzed to generate a cause-effect relation map based on the degree of influence among the criteria. In Eq. 8, the sum of each row is denoted by $r$, while in Eq. 9, the sum of each column is denoted by $d$ :

$\boldsymbol{r}=\left(r_{1}, \ldots, r_{i}, \ldots, r_{n}\right)^{\prime}=\left[t_{i}\right]_{n \times 1}=\left[\sum_{j=1}^{n} t_{i j}\right]_{n \times 1}$

$\boldsymbol{d}=\left(d_{1}, \ldots, d_{i}, \ldots, d_{n}\right)^{\prime}=\left[t_{j}\right]_{n \times 1}=\left[\sum_{i=1}^{n} t_{i j}\right]_{n \times 1}^{\prime}$.

In this study, $r_{i}$ denotes the sum of the $i$ th row of matrix $\boldsymbol{T}$ and also represents the sum of the direct and indirect effects of criterion $i$ on other criteria. While $d_{j}$ represents the sum of the $j$ th column of matrix $\boldsymbol{T}$, it also represents the sum of the direct and indirect influences of criterion $j$ on other criteria.

When $i=j$, the $\left(r_{i}+d_{i}\right)$ value represents the degree of influence of each criterion. The $\left(r_{i}+d_{i}\right)$ value is known as the prominence, which shows the degree of the central role played by this particular criterion in the system ( $\mathrm{Li}$ and Tzeng 2009; Maqbool and Khan 2020). Conversely, the $\left(r_{i}-d_{i}\right)$ value represents the degree of influence received by criteria $i$ from other criteria. A higher $\left(r_{i}-d_{i}\right)$ value means that criterion $i$ has a stronger connection with the other criteria in the system. A higher $\left(r_{i}-d_{i}\right)$ value means that this criterion has a stronger influence on other criteria than the influence that is received from them (Zhang et al. 2019).

The difference $\left(r_{i}-d_{i}\right)$ can be used to divide the criteria into two groups, namely the cause-and-effect groups. If $\left(r_{i}-d_{i}\right)$ is positive, it means that the criterion affects other criteria. In other words, the criterion belongs to the cause group. When $\left(r_{i}-d_{i}\right)$ is negative, it means that the criterion is affected by other criteria. In other words, the criterion belongs to the net effect group. Using this method, the cause-effect influence relations among the dimensions and criteria can be determined by $\left(r_{i}-d_{i}\right)$. Moreover, the INRM can be constructed to delineate the influential relationship diagram for further analysis and provide insights about wealth bank management. Table 3 lists the symbols used in this study.

\section{Results}

\section{Three dimensions}

We used the DEMATEL technique to identify the network relationships among the criteria affecting the wealth management banks. The prominence $\left(r_{i}+d_{i}\right)$ and net effect $(r-d)$ were calculated from the total relation matrix. The INRM for the three dimensions of performance, professionalism,

Table 3 List of symbols

\begin{tabular}{ll}
\hline Term & Definition \\
\hline$R$ & Initial direct influence relation matrix \\
$A$ & Average direct influence relation matrix \\
$X$ & Normalize average direct influence relation matrix \\
$I$ & Identity matrix \\
$T$ & Total influence relation matrix \\
$r$ & Degree of influence \\
$d$ & Degree of to be influenced \\
$r+d$ & Total influence degree \\
$r-d$ & Net influence (influence received-influence sent)
\end{tabular}




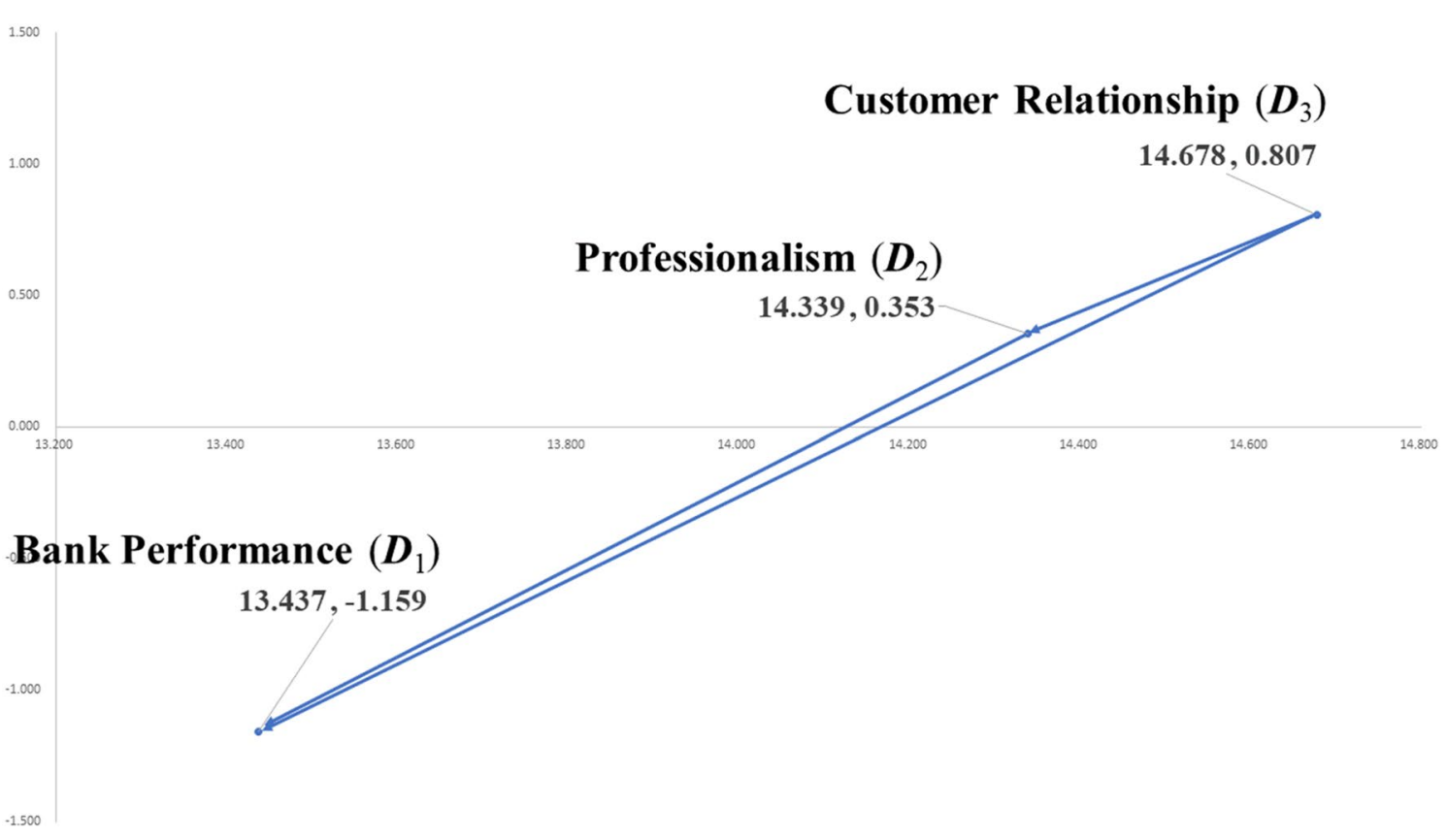

Fig. 3 INRM of the three dimensions

Table 4 The degree of influence of the three dimensions

\begin{tabular}{llllllll}
\hline$T$ & $D_{1}$ & $D_{2}$ & $D_{3}$ & $r$ & $d$ & $r+d$ & $r-d$ \\
\hline$D_{1}$ & 1.929 & 2.115 & 2.095 & 6.139 & 7.298 & 13.437 & -1.159 \\
$D_{2}$ & 2.603 & 2.214 & 2.529 & 7.346 & 6.993 & 14.339 & 0.353 \\
$D_{3}$ & 2.766 & 2.664 & 2.312 & 7.742 & 6.936 & 14.678 & 0.807 \\
\hline
\end{tabular}

Based on the $\left(r_{i}+d_{i}\right)$ value, customer relationship $\left(D_{3}\right)$ had the highest prominence (14.678), followed by professionalism $\left(D_{2} ; 14.339\right)$ and key performance $\left(D_{1} ; 13.437\right)$. From the $\left(r_{i}-d_{i}\right)$ values, the criteria were divided into two groups. Customer relationship $\left(D_{3} ; 0.807\right)$ and professionalism $\left(D_{2}, 0.353\right)$ were the causes. Key performance $\left(D_{1} ;-1.159\right)$ was the effect. and customer behavior is depicted in Fig. 3. Table 4 shows the degree of influence of the three dimensions.

Based on the $\left(r_{i}+d_{i}\right)$ values in Table 4 , the prominence was ranked in the order of customer relationship $\left(D_{3}\right.$; 14.678), professionalism $\left(D_{2} ; 14.339\right)$, and bank performance $\left(D_{1} ; 13.437\right)$. Based on the $\left(r_{i}-d_{i}\right)$ value in Table 4 , the net causes included customer relationship $\left(D_{3} ; 0.807\right)$ and professionalism $\left(D_{2} ; 0.353\right)$. The net effect was bank performance $\left(D_{1} ;-1.159\right)$.

Subsequently, this study obtained the influences of the criteria for each of the three dimensions.

\section{Key performance $\left(D_{1}\right)$}

The dimension of key performance $\left(D_{1}\right)$ consisted of five criteria: CIF, AUM, fee income, commission income, and customer satisfaction. The network relationships among the five criteria are shown in Fig. 4. Table 5 shows the degree of influence of each criterion in $\boldsymbol{D}_{1}$.
Based on the $\left(r_{i}+d_{i}\right)$ values presented in Table 5, the prominence was ranked in the order of customer satisfaction $\left(C_{5} ; 17.234\right)$, fee income $\left(C_{3} ; 17.210\right), \operatorname{CIF}\left(C_{1} ; 16.546\right)$, assets under management $\left(C_{2} ; 16.414\right)$, and commission income $\left(C_{4} ; 16.116\right)$. Based on the $\left(r_{i}-d_{i}\right)$ value in Table 5 , the net causes included customer satisfaction $\left(C_{5} ; 1.075\right)$ and CIF $\left(C_{1} ; 0.957\right)$. The net effects (receivers) were ranked in the order of commission income $\left(C_{4} ;-0.892\right)$, fee income $\left(C_{3} ;-0.865\right)$, and assets under management $\left(C_{2} ;-0.276\right)$.

\section{Professionalism $\left(D_{2}\right)$}

The dimension of professionalism $\left(D_{2}\right)$ consisted of three criteria: innovative products and services, comprehensive investment information, and family financial planning. The network relationships among the five criteria are shown in Fig. 5. Table 6 shows the degree of influence of each criterion in $D_{2}$.

Based on the $\left(r_{i}+d_{i}\right)$ values presented in Table 6 , the prominence was ranked in the order of innovative products 


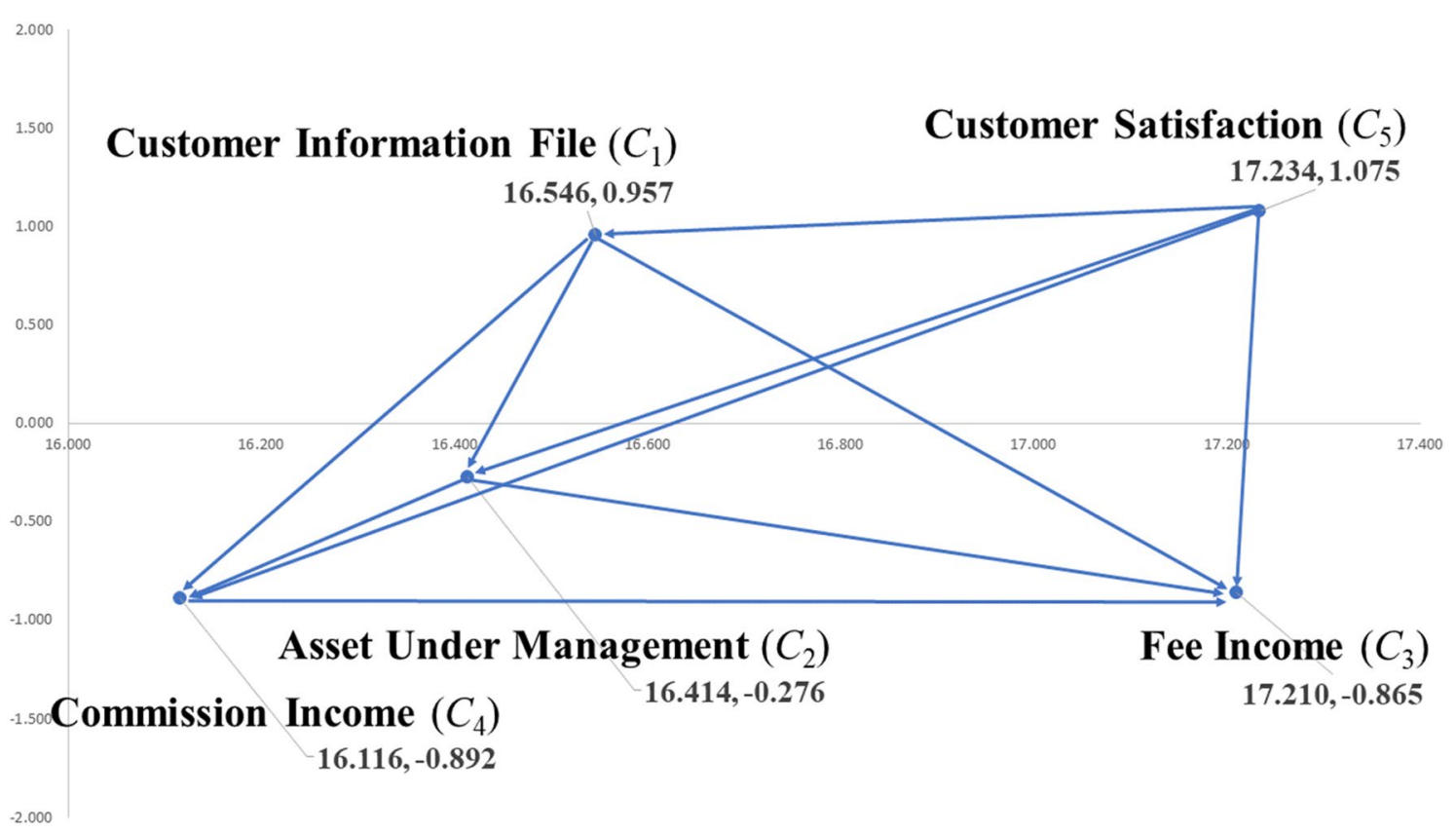

Fig. 4 INRM of the five criteria within $\boldsymbol{D}_{1}$

Table 5 The degree of influence of each criterion in $D_{1}$

\begin{tabular}{lllllllllr}
\hline$T$ & $C_{1}$ & $C_{2}$ & $C_{3}$ & $C_{4}$ & $C_{5}$ & $r$ & $d$ & $r+d$ & $r-d$ \\
\hline$C_{1}$ & 1.491 & 1.791 & 1.920 & 1.808 & 1.741 & 8.751 & 7.794 & 16.546 & 0.957 \\
$C_{2}$ & 1.545 & 1.471 & 1.778 & 1.681 & 1.593 & 8.069 & 8.345 & 16.414 & -0.276 \\
$C_{3}$ & 1.564 & 1.665 & 1.614 & 1.697 & 1.632 & 8.172 & 9.037 & 17.210 & -0.865 \\
$C_{4}$ & 1.433 & 1.569 & 1.698 & 1.414 & 1.498 & 7.612 & 8.504 & 16.116 & -0.892 \\
$C_{5}$ & 1.761 & 1.848 & 2.026 & 1.903 & 1.617 & 9.155 & 8.080 & 17.234 & 1.075 \\
\hline
\end{tabular}

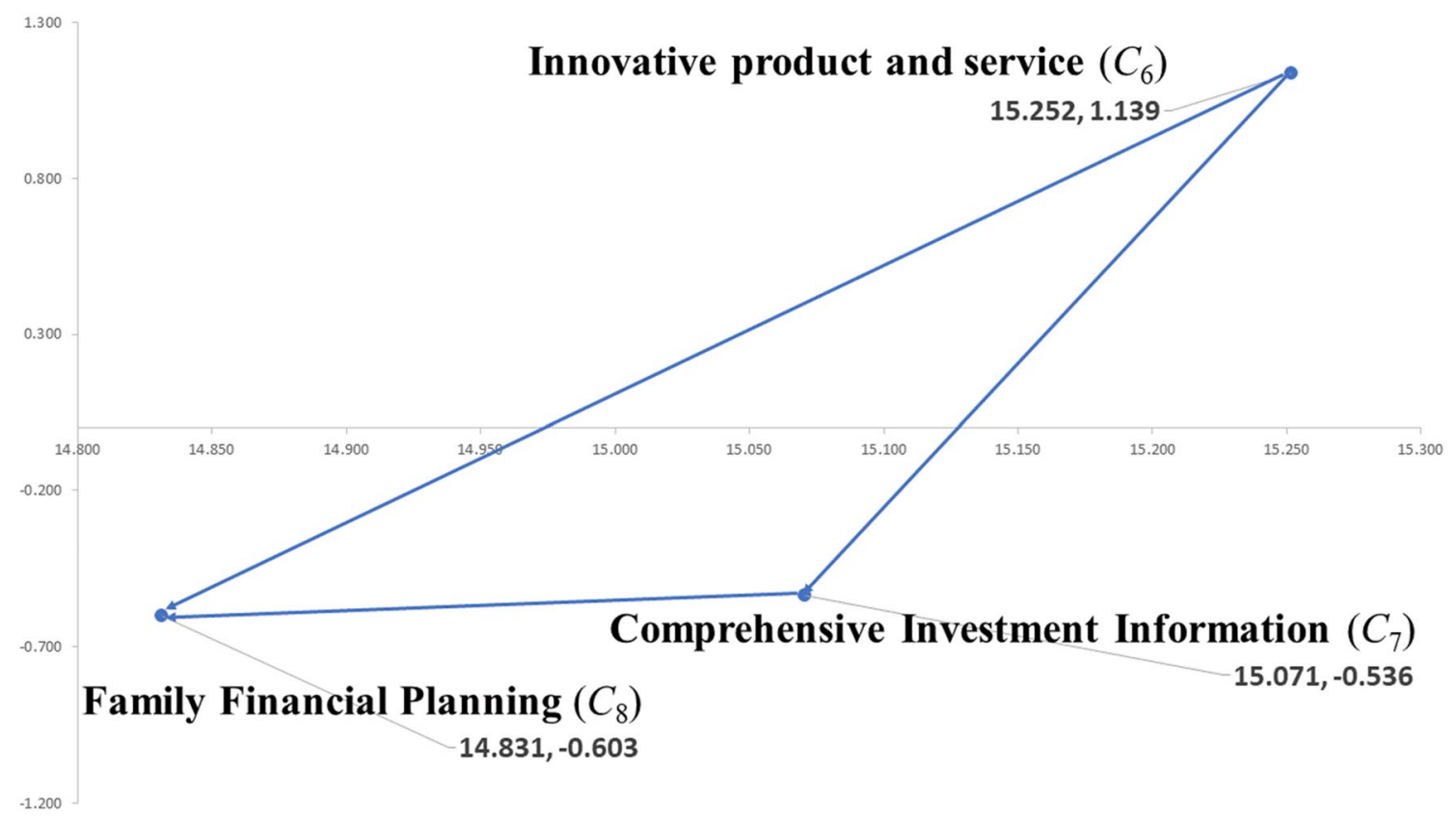

Fig. 5 INRM of the three criteria in $\boldsymbol{D}_{2}$ 
and services $\left(D_{6} ; 15.252\right)$, comprehensive investment information $\left(D_{7} ; 15.071\right)$, and family financial planning $\left(D_{8}\right.$; 14.831). Based on the $\left(r_{i}-d_{i}\right)$ value in Table 6 , the only net cause was innovative products and services $\left(C_{6} ; 1.139\right)$. The net effects (receivers) were ranked in the order of family financial planning $\left(C_{8} ;-0.603\right)$ and comprehensive investment information $\left(C_{7} ;-0.536\right)$.

\section{Customer relationship $\left(D_{3}\right)$}

The dimension of customer relationship consisted of five criteria: customer involvement, relationship bond, benefit of switching, cost of switching, and switching behavior. The network relationship among these criteria is depicted in Fig. 6. Table 7 shows the degree of influence of each criterion in customer relationship $\left(D_{3}\right)$.

Based on the $\left(r_{i}+d_{i}\right)$ values presented in Table 7 , the prominence was ranked in the order of switching behavior $\left(C_{13} ; 16.993\right)$, benefit of switching $\left(C_{11} ; 16.301\right)$, customer
Table 6 The degree of influence of each criterion in $\mathrm{D}_{2}$

\begin{tabular}{lllllllr}
\hline$T$ & $C_{6}$ & $C_{7}$ & $C_{8}$ & $r$ & $d$ & $r+d$ & $r-d$ \\
\hline$C_{6}$ & 2.353 & 2.949 & 2.894 & 8.195 & 7.056 & 15.252 & 1.139 \\
$C_{7}$ & 2.371 & 2.307 & 2.589 & 7.267 & 7.803 & 15.071 & -0.536 \\
$C_{8}$ & 2.332 & 2.548 & 2.234 & 7.114 & 7.717 & 14.831 & -0.603 \\
\hline
\end{tabular}

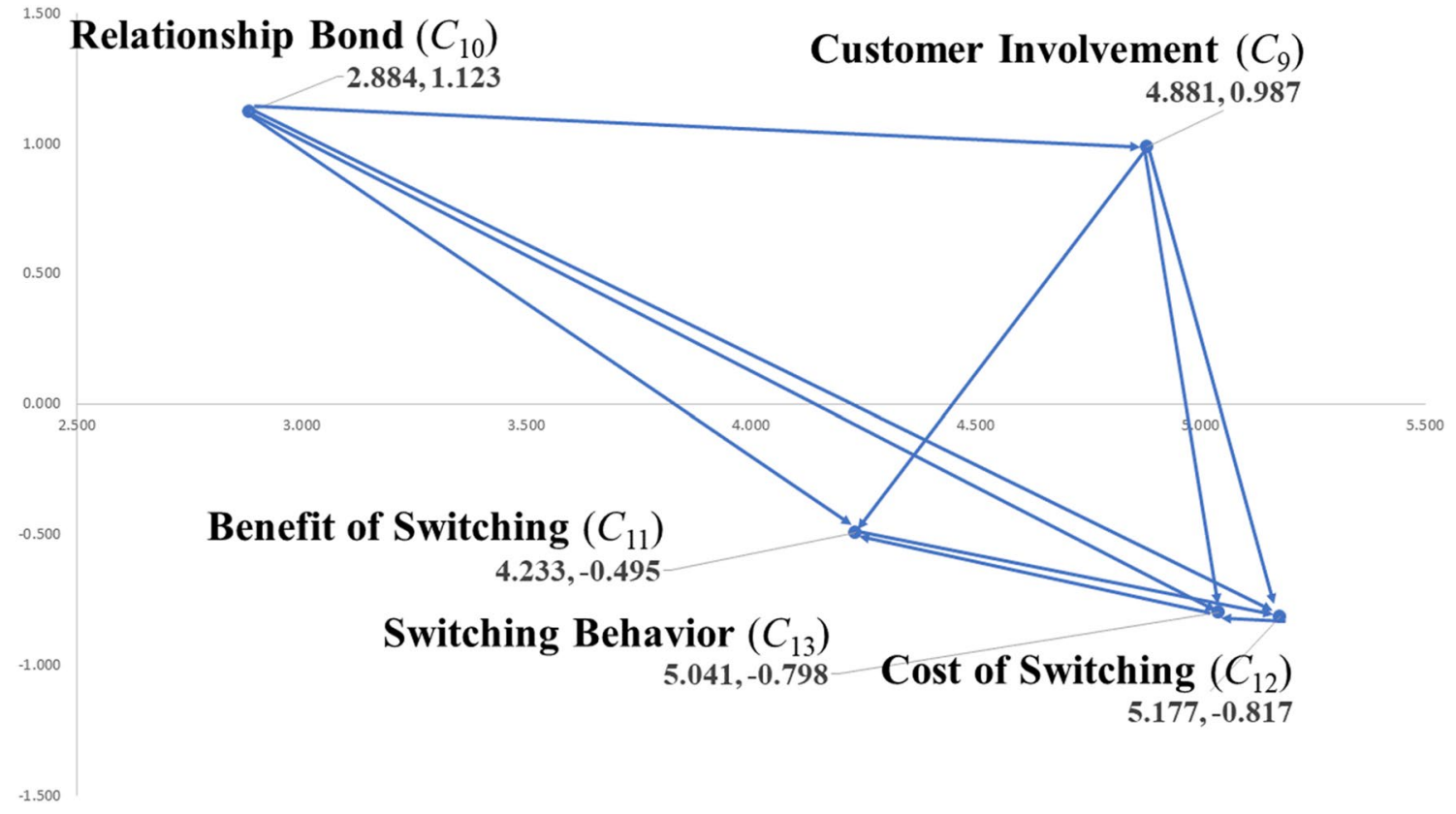

Fig. 6 Network relationships among the criteria in $\boldsymbol{D}_{3}$

Table 7 The degree of influence of each criterion in $D_{3}$

\begin{tabular}{llllllllll}
\hline$T$ & $C_{9}$ & $C_{10}$ & $C_{11}$ & $C_{12}$ & $C_{13}$ & $r$ & $d$ & $r+d$ & $r-d$ \\
\hline$C_{9}$ & 1.463 & 1.607 & 1.784 & 1.658 & 1.892 & 8.405 & 7.613 & 16.018 & 0.793 \\
$C_{10}$ & 1.547 & 1.312 & 1.652 & 1.524 & 1.748 & 7.784 & 7.369 & 15.153 & 0.415 \\
$C_{11}$ & 1.578 & 1.503 & 1.519 & 1.593 & 1.800 & 7.993 & 8.308 & 16.301 & -0.314 \\
$C_{12}$ & 1.410 & 1.382 & 1.580 & 1.292 & 1.663 & 7.328 & 7.708 & 15.036 & -0.380 \\
$C_{13}$ & 1.614 & 1.564 & 1.773 & 1.640 & 1.649 & 8.240 & 8.753 & 16.993 & -0.513 \\
\hline
\end{tabular}


Table 8 Ranking of criteria based on influence

\begin{tabular}{|c|c|c|c|c|c|c|}
\hline Rank & Dimension & $\left(r_{i}+d_{i}\right)$ & Rank & Criteria no & Criteria & $\left(r_{i}+d_{i}\right)$ \\
\hline \multirow[t]{5}{*}{1} & \multirow[t]{5}{*}{ Customer relationship (D3) } & \multirow[t]{5}{*}{14.678} & 1 & $C_{13}$ & Switching behavior & 16.993 \\
\hline & & & 2 & $C_{11}$ & Benefit of switching & 16.301 \\
\hline & & & 3 & $C_{9}$ & Customer involvement & 16.018 \\
\hline & & & 4 & $C_{10}$ & Relationship bond & 15.153 \\
\hline & & & 5 & $C_{12}$ & Cost of switching & 15.036 \\
\hline \multirow[t]{3}{*}{2} & \multirow[t]{3}{*}{ Professionalism } & \multirow[t]{3}{*}{14.339} & 1 & $C_{6}$ & Innovative product and service & 15.252 \\
\hline & & & 2 & $C_{7}$ & Comprehensive investment information & 15.071 \\
\hline & & & 3 & $C_{8}$ & Family financial planning & 14.831 \\
\hline \multirow[t]{5}{*}{3} & \multirow[t]{5}{*}{ Key performance } & \multirow[t]{5}{*}{13.437} & 1 & $C_{5}$ & Customer satisfaction & 17.234 \\
\hline & & & 2 & $C_{3}$ & Fee income & 17.210 \\
\hline & & & 3 & $C_{1}$ & Customer information file & 16.546 \\
\hline & & & 4 & $C_{2}$ & Asset under management & 16.414 \\
\hline & & & 5 & $C_{4}$ & Commission income & 16.116 \\
\hline
\end{tabular}

Table 9 The net cause-and-effect group

\begin{tabular}{|c|c|c|c|c|c|c|c|c|}
\hline Rank & Dimension & $r_{i}-d_{i}$ & & Rank & Criteria no & Criteria & $r_{i}-d_{i}$ & \\
\hline \multirow[t]{5}{*}{1} & Customer relationship & 0.807 & CAUSE & 1 & $C_{9}$ & Customer involvement & 0.793 & CAUSE \\
\hline & & & & 2 & $C_{10}$ & Relationship bond & 0.415 & CAUSE \\
\hline & & & & 3 & $C_{11}$ & Benefit of switching & -0.314 & EFFECT \\
\hline & & & & 4 & $C_{12}$ & Cost of switching & -0.380 & EFFECT \\
\hline & & & & 5 & $C_{13}$ & Switching behavior & -0.513 & EFFECT \\
\hline \multirow[t]{3}{*}{2} & Professionalism & 0.353 & CAUSE & 1 & $C_{6}$ & Innovative product and service & 1.139 & CAUSE \\
\hline & & & & 2 & $C_{7}$ & Comprehensive investment information & -0.539 & EFFECT \\
\hline & & & & 3 & $C_{8}$ & Family financial planning & -0.603 & EFFECT \\
\hline \multirow[t]{5}{*}{3} & Key performance & -1.159 & EFFECT & 1 & $C_{5}$ & Customer satisfaction & 1.043 & CAUSE \\
\hline & & & & 2 & $C_{1}$ & CIF & 0.957 & CAUSE \\
\hline & & & & 3 & $C_{4}$ & Commission income & -0.276 & EFFECT \\
\hline & & & & 4 & $C_{3}$ & Fee income & -0.865 & EFFECT \\
\hline & & & & 5 & $C_{2}$ & AUM & -0.892 & EFFECT \\
\hline
\end{tabular}

involvement $\left(C_{9} ; 16.018\right)$, relationship bond $\left(C_{10} ; 15.153\right)$, and cost of switching $\left(C_{12} ; 15.036\right)$. Based on the $\left(r_{i}-d_{i}\right)$ value in Table 7 , the net causes (receivers) were ranked in the order of customer involvement $\left(C_{9} ; 0.793\right)$ and relationship bond $\left(C_{10} ; 0.415\right)$. The net effects (receivers) were ranked in the order of switching behavior $\left(C_{13} ;-0.513\right)$, cost of switching $\left(C_{12} ;-0.380\right)$, and benefit of switching $\left(C_{11} ;-0.314\right)$.

Table 8 presents the ranking of the criteria based on influence. Table 9 exhibits the cause-and-effect groups.

\section{Discussion and managerial implications}

\section{Discussion}

According to both the prominence $\left(r_{i}+d_{i}\right)$ and causeand-effect relationships among the dimensions $\left(r_{i}-d_{i}\right)$, we found that customer relationship $\left(D_{3}\right)$ has the highest influence on the other criteria, followed by professionalism $\left(D_{2}\right)$. Key performance $\left(D_{1}\right)$ is the receiver of influence. Specifically, customer relationship is the primary and professionalism the secondary cause, while key performance is the only effect.

Previous studies analyzed bank performance mostly using the AHP method from the product and service perspectives (Wu et al. 2011; Chang and Tsai 2016; Ting 2017). This research utilized a combination of the Delphi 
method to obtain experts' opinions and the DEMATEL method to identify the influential relationships among the three dimensions as well as the criteria within each dimension. The detection of the cause-and-effect group could allow banks to focus directly on the causes and expect the effects to be visible.

This study offers an up-to-date analysis on bank evaluation during the COVID-19 period. The results were consistent with the literature, which has found that financial institutions must recognize the customers' changing needs and provide personalized services to high-net-worth individuals (Brunel 2011; Ugolini 2018). In addition, wealth management banks that have not caught up with the changing patterns during the crisis may not prevail in the fierce competition of banking services (Ting 2017).

\section{Managerial implications}

The results of this study suggested that customer relationship and professionalism affect key performance and that customer relationship plays a central role. Consistent with the research report by the McKinsey Company (2020), the severity of COVID-19 has altered bank practices in serving their wealth management customers. In order to attract and retain customers during the COVID-19 period, banks seek to deepen their relationships with customers. As a result, banks recommended personalized products to increase customer usage, developed innovative products and services, thus increasing the CIF, AUM, and fee and commission income. These results are consistent with previous studies that emphasized the significant impact of relationship quality on customer loyalty (Ting 2017; Yeh 2015). However, the results of this study vary from that of prior studies. Previous researches highlighted that consumer confidence and risk control were critical pursuant to the 2008 financial crisis (Chan and Chan 2011; Chang and Tsai 2016; Yeh 2015). In contrast, this study focused on the current digital era, revealing that customer relationships and innovative products are crucial to high-net-worth customers.

The implications drawn from the results of this study can be explained from the three dimensions.

Within the dimension of key performance $\left(D_{1}\right)$, customer satisfaction $\left(C_{5}\right)$ has the highest influence based on the value of $\left(r_{i}-d_{i}\right)$, followed by CIF $\left(C_{1}\right)$. These two criteria affect $\operatorname{AUM}\left(C_{2}\right)$, fee income $\left(C_{3}\right)$, and commission income $\left(C_{4}\right)$. Customer satisfaction $\left(C_{5}\right)$ is the most influential criterion based on the value of $\left(r_{i}+d_{i}\right)$. This outcome suggested that banks may focus on increasing customer satisfaction to excel, which is consistent with Tadic et al. (2018) and Grigoroudis et al. (2012). For example, one bank executive mentioned, "Customers are satisfied when the bank financial advisors understand what they need and provide personalized services for themselves and their family members."
Moreover, CIF influences bank performance. During the COVID-19 period, wealth management customers have tended to select large and reputable banks because customers feel secure with big banks that have a proven track record of success. Therefore, large banks may seize the opportunity to target high-net-worth individuals and offer customized services during financial turbulence.

Within the dimension of professionalism $\left(D_{2}\right)$, innovative products and services $\left(C_{6}\right)$ affects comprehensive investment information $\left(C_{7}\right)$ and family financial planning $\left(C_{8}\right)$, based on the value of $\left(r_{i}-d_{i}\right)$. Innovative products and services is the most influential criterion, based on the value of $\left(r_{i}+d_{i}\right)$, which was consistent with Wu et al. (2010), Phoon and Koh (2018), and Semko (2019). Therefore, banks should develop new and innovative financial services to provide customers with a wide range of information, including ways to transfer the family wealth to the next generation. For example, banks may develop FinTech and robot-advisors to recommend investment portfolios for high-net-worth individuals or family members based on their personal or family characteristics. Financial advisors may use the bank's automatic systems to suggest hedging investment portfolios for customers when markets become more volatile. Financial advisors may also assist customers in giving "stop-loss" and "take-profit" instructions and send such notifications automatically to customers to avoid possible losses and reap gains during times of high volatilities. For example, one bank executive mentioned, "Bank B uses big data to find customers who have been affected by COVID-19, and then the bank managers ensure that the financial advisors communicate the necessary actions to those customers." Another bank executive mentioned, "Bank A has developed an innovative system to track combined family balances to ensure that customers and their family members always enjoy bank privileges, such as VIP counters, personal financial consultation, lower service charges, and free airport pick-up.” Banks may also use a new system to track customers' family members so that bank advisors may provide estate planning services, which are highly needed by affluent families but are inadequately discussed in traditional Asian families.

Within the dimension of customer relationship $\left(D_{3}\right)$, customer involvement $\left(C_{9}\right)$ affects other criteria the most, followed by relationship bond $\left(C_{10}\right)$, based on the value of $\left(r_{i}-d_{i}\right)$. The affected criteria include switching behavior $\left(C_{13}\right)$, cost of switching $\left(C_{12}\right)$, and benefit of switching $\left(C_{11}\right)$. The most influential criterion is switching behavior $\left(C_{13}\right)$, based on the value of $\left(r_{i}+d_{i}\right)$. These results suggest that banks may strengthen their relationship bond with customers by increasing their usage of personalized products and services. This finding was consistent with the works by Ananth et al. (2010) and Benoit and Van den Poel (2012) that increasing customer usage of products and services through cross-selling strengthens the relationship between 
banks and clients. Therefore, banks should encourage their customers to use products (mutual funds, ETFs, bonds, foreign exchange, etc.) and services (online banking, mobile banking, robot-advisors, etc.) more frequently. Moreover, the outcome corresponds to the work of Hsu (2014) and Mutum et al. (2014) which highlighted customer decisions' to switch banks when the benefits of switching exceed the costs of switching.

Due to the fear of COVID-19, a growing number of customers have refrained from stepping into banks; therefore, banks have developed services that do not require human contact. These new contactless services, such as online communication with financial advisors and the delivery of investment information through mobile devices, have increased their popularity because banks and customers can avoid direct human interaction with each other. Moreover, banks may contact their customers through short text messages or e-mail to update their investment performance. Special programs with deeper discounts for customers could reinforce the relationship bonding effect. For example, one bank executive mentioned, "Bank $\mathrm{C}$ first classifies their customers by their occupation, such as self-employed businessmen, high-level managers of listed companies, or professional workers (lawyers and accountants), then provides customized services, including asset allocation, tax planning, and even medical care." Another bank executive mentioned, "Bank A has protected customers' assets by providing appropriate investment strategies and sending personalized information to customers through short messages, line messages, or internet banking systems during the COVID-19 period." In short, banks can attempt to deepen the relationships with their customers by cross-selling and increasing bank product usage. Such bonding efforts are likely to influence customers' intention and behavior to remain with the same bank. Furthermore, banks that have responded quickly to the COVID-19 pandemic have been able to succeed in customer acquisition and loyalty.

\section{Conclusions, limitations, and future research}

Wealth management has grown tremendously in Taiwan over the last decade, which has increased the proportion of fee and commission income for the banks. This study applied the Delphi and DEMATEL method in its research. Based on the inputs from 17 bank experts, we identified the influential network relationships among 13 criteria within three dimensions: key performance (CIF, AUM, fee income, commission income, customer satisfaction); professionalism (innovative products and services, comprehensive investment information, family financial planning); and customer relationships (customer involvement, relationship bond, cost of switching, benefit of switching, switching behavior).
The empirical findings of this study could be summarized as follows: Customer relationship $\left(D_{3}\right)$ is the most important cause, followed by professionalism $\left(D_{2}\right)$. These two dimensions affect key performance $\left(D_{1}\right)$.

Within the first dimension of key performance $\left(D_{1}\right)$, customer satisfaction and CIF are the causes, while AUM, fee income, and commission income are the effects, with customer satisfaction being the most influential criterion. This outcome was consistent with the study of $\mathrm{Wu}$ et al. (2010). Within the second dimension of professionalism $\left(D_{2}\right)$, innovative products and services is the cause, while comprehensive investment information and family financial planning are the effects. Innovative products and services is the most influential criterion. This finding was consistent with Phoon and Koh (2018) and Semko (2019), who emphasized the digitalization of services. Within the third dimension of customer relationships $\left(D_{3}\right)$, customer involvement is the primary cause, followed by relationship bond. The affected criteria are switching behavior, cost of switching, and benefit of switching. Switching behavior is the most influential criterion. This outcome corresponds to the works by Ananth et al. (2010), and Benoit and Van den Poel (2012) that increasing customer usage of products and services through cross-selling strengthens the relationship between banks and clients. Therefore, banks should encourage their customers to use personalized products (mutual funds, ETFs, bonds, foreign exchange, etc.) and services (online banking, mobile banking, robot-advisors, etc.) more frequently to enjoy the bank benefits.

Our study contributes to the understanding of the ways in which the COVID-19 pandemic has changed wealth management bank practices. We applied the DEMATEL technique on bank-specific criteria to determine the priority. As a result, we provided practical suggestions for bank managers. Wealth management bank may improve their performance through strengthening customer relationship as well as developing innovative products and services. However, a limitation of this study is that it only covers the COVID-19 pandemic period. Future research may include a comparison of wealth management bank services before, during, and after the COVID-19 pandemic.

Funding This research was funded by the Ministry of Science and Technology, Taiwan, grant numbers MOST 107-2410-H-305038-MY3, MOST 108-2221-E-305-002-MY3, and MOST 109-2410-H-305-056. 


\section{References}

Abedifar, P., P. Molyneux, and A. Tarazi. 2018. Non-interest income and bank lending. Journal of Banking and Finance 87: 411-426. https://doi.org/10.1016/j.jbankfin.2017.11.003.

Ananda, S., S. Devesh, and A.M. Al Lawati. 2020. What factors drive the adoption of digital banking? An empirical study from the perspective of Omani retail banking. Journal of Finance Service Marking 25: 14-24. https://doi.org/10.1057/s41264-020-00072-y.

Ananth, A., Prabaharan, B. and Ramesh, R. 2010. Service quality gap analysis in private sector bank: A customer perspective. https:// mpra.ub.uni-muenchen.de/id/eprint/29505

Ang, S. 2010. A qualitative study on the challenges of private banking in Asia. The Journal of Wealth Management 12 (4): 68-77. https:// doi.org/10.3905/jwm.2010.12.4.068.

Barroso, C., and A. Picón. 2012. Multi-dimensional analysis of perceived switching costs. Industrial Marketing Management 41 (3): 531-543. https://doi.org/10.1016/j.indmarman.2011.06.020.

Beaverstock, J.V., S. Hall, and T. Wainwright. 2013. Servicing the super-rich: New financial elites and the rise of the private wealth management retail ecology. Regional Studies 47 (6): 834-849. https://doi.org/10.1080/00343404.2011.587795.

Benoit, D.F., and D. Van den Poel. 2012. Improving customer retention in financial services using kinship network information. Expert Systems with Applications 39 (13): 11435-11442. https://doi.org/ 10.1016/j.eswa.2012.04.016.

Blut, M., H. Evanschitzky, C. Backhaus, J. Rudd, and M. Marck. 2016. Securing business-to-business relationships: The impact of switching costs. Industrial Marketing Management 52: 82-90. https://doi.org/10.1016/j.indmarman.2015.05.010.

Business Today (2020) Wealth Management Bank and Securities Award (in Chinese) https://www.businesstoday.com.tw/catalog/ 168205

Brunel, J.L.P. 2011. Goal-based wealth management in practice. The Journal of Wealth Management Winter 14 (3): 17-26. https://doi. org/10.3905/jwm.2011.14.3.017.

Business Weekly. 2018. Fight between Taiwan domestic and foreign banks to serve high-end customers. 10 November, https://wealth. businessweekly.com.tw/GArticle.aspx?id=ARTL000120098. Accessed 10 Nov 2020.

Centers for Disease Control and Prevention. 2020. How COVID-19 spreads, https://www.cdc.gov/coronavirus/2019-ncov/preventgetting-sick/how-covid-spreads.html. Accessed 11 Nov 2020.

Chan, C., and A. Chan. 2011. Attitude toward wealth management services: Implications for international banks in China. International Journal of Bank Marketing 29 (4): 272-292. https://doi.org/10. 1108/02652321111145925

Chang, S., and P. Tsai. 2016. A hybrid financial performance evaluation model for wealth management banks following the global financial crisis. Technological and Economic Development of Economy 22 (1): 21-46. https://doi.org/10.3846/20294913.2014.986771.

Deloitte. (2020) The COVID-19 pandemic: Disruptor or accelerator? How wealth managers can recover and thrive. https://www2.deloi tte.com/content/dam/Deloitte/us/Documents/financial-services/ covid-19-wealth-management-pov.pdf. Accessed 11 Nov 2020.

Doumpos, M., C. Gaganis, and F. Pasiouras. 2016. Bank diversification and overall financial strength: International evidence: Bank diversification and overall financial strength. Financial Markets, Institutions \& Instruments 25 (3): 169-213. https://doi.org/10. 1111/fmii.12069.

Focus Taiwan .2020. Coronavirus/Taiwan cuts 2020 GDP growth forecast due to COVID-19 impact, https://focustaiwan.tw/business/ 202005280019

Fontela, E., and A. Gabus 1976. The DEMATEL observer. Battelle Geneva research center, Geneva. https://www.scirp.org/(S(czeh2
tfqyw2orz553k1w0r45))/reference/ReferencesPapers.aspx?Refer enceID $=1847241$, accessed 10 November 2020 .

Geiger, I., A. Durand, S. Saab, M. Kleinaltenkamp, R. Baxter, and Y. Lee. 2012. The bonding effects of relationship value and switching costs in industrial buyer-seller relationships: An investigation into role differences. Industrial Marketing Management 41 (1): 82-93. https://doi.org/10.1016/j.indmarman.2011.11.013.

Grigoroudis, E., E. Tsitsiridi, and C. Zopounidis. 2012. Linking customer satisfaction, employee appraisal, and business performance: An evaluation methodology in the banking sector. Annals of Operations Research 205 (1): 5-27. https://doi.org/10.1007/ s10479-012-1206-2.

Guido, G., C. Amatulli, and A. Sestino. 2020. Elderly consumers and financial choices: A systematic review. Journal of Financial Service Marketing 25: 76-85. https://doi.org/10.1057/ s41264-020-00077-7.

Gunardi, H., I. Primiana, N. Effendi, and A. Herwany. 2020. The performance of private wealth management in Indonesia. Journal of Asian Finance, Economics and Business 7 (11): 717-725.

Hackethal, A., M. Haliassos, and T. Jappelli. 2012. Financial advisors: A case of babysitters? Journal of Banking \& Finance 36 (2): 509-524. https://doi.org/10.1016/j.jbankfin.2011.08.008.

Haenlein, M., A.M. Kaplan, and A.J. Beeser. 2007. A model to determine customer lifetime value in a retail banking context. European Management Journal 25 (3): 221-234. https://doi.org/10. 1016/j.emj.2007.01.004

Hsu, J.S. 2014. Understanding the role of satisfaction in the formation of perceived switching value. Decision Support Systems 59: 152-162. https://doi.org/10.1016/j.dss.2013.11.003.

Jennings, W.W., S.M. Horan, W. Reichenstein, and J.L.P. Brunel. 2011. Perspective from the literature of private wealth management. The Journal of Wealth Management Summer 14 (1): 8-40. https://doi.org/10.3905/jwm.2011.14.1.008.

Komulainen, H., and H. Makkonen. 2018. Customer experience in omni-channel banking services. Journal of Financial Service Marketing 23: 190-199. https://doi.org/10.1057/ s41264-018-0057-6.

Lee, H., G. Tzeng, W. Yeih, Y. Wang, and S. Yang. 2013. Revised DEMATEL: Resolving the infeasibility of DEMATEL. Applied Mathematical Modelling 37 (10-11): 6746-6757. https://doi.org/ 10.1016/j.apm.2013.01.016.

Lee, K.J., and S.L. Lu. 2021. The Impact of COVID-19 on the Stock Price of Socially Responsible Enterprises: An Empirical Study in Taiwan Stock Market. International Journal of Environmental Research and Public Health 18 (4): 2040-2052. https://doi.org/ 10.1080/1540496X.2017.1343141.

$\mathrm{Li}, \mathrm{C}$., and G. Tzeng. 2009. Identification of a threshold value for the DEMATEL method using the maximum mean de-entropy algorithm to find critical services provided by a semiconductor intellectual property mall. Expert Systems with Applications 36 (6): 9891-9898. https://doi.org/10.1016/j.eswa.2009.01.073.

Lin, P.J., Y.C. Shiue, G.H. Tzeng, and S.L. Huang. 2019. Developing a sustainable long-term ageing health care system using the DANP$\mathrm{mV}$ model: Empirical case of Taiwan. International Journal of Environmental Research and Public Health 16 (8): 1349.

Maqbool, A., and N.Z. Khan. 2020. Analyzing barriers for implementation of public health and social measures to prevent the transmission of COVID-19 disease using DEMATEL method. Diabetes \& Metabolic Syndrome: Clinical Research \& Reviews 14 (5): 887-892. https://doi.org/10.1016/j.dsx.2020.06.024.

McKinsey Company. 2020. Wealth Management in Asia: Navigating the impact of coronavirus. https://www.mckinsey.com/ / media/McKinsey/Industries/Financial\%20Services/Our\%20Ins ights/Wealth $\% 20$ management $\% 20$ in $\% 20$ Asia\% 20Navigati ng\%20the\% 20impact\%20o\% 20coronavirus/Wealth-manag 
ement-in-Asia-navigating-the-impact-of-coronavirus-final.ashx. Accessed 9 Nov 2020.

Mihelis, G., E. Grigoroudis, Y. Siskos, Y. Politis, and Y. Malandrakis. 2001. Customer satisfaction measurement in the private bank sector. European Journal of Operational Research 130 (2): 347-360. https://doi.org/10.1016/s0377-2217(00)00036-9.

Milan, G.S., L.A. Slongo, L. Eberle, D. De. Toni, and S. Bebber. 2018. Determinants of customer loyalty: A study with customers of a Brazilian bank. Benchmarking: An International Journal 25 (9): 3935-3950. https://doi.org/10.1108/bij-08-2017-0231.

Murry, J.W., and J.O. Hammons. 1995. Delphi: A versatile methodology for conducting qualitative research. Review of Higher Education 18 (4): 423-436. https://doi.org/10.1353/rhe.1995.0008.

Mutum, D., E. Mohd Ghazali, B. Nguyen, and D. Arnott. 2014. Online loyalty and its interaction with switching barriers. Journal of Retailing and Consumer Services 21 (6): 942-949. https://doi. org/10.1016/j.jretconser.2014.08.012.

Nisar, S., K. Peng, S. Wang, and B. Ashraf. 2018. The impact of revenue diversification on bank profitability and stability: Empirical evidence from South Asian countries. International Journal of Financial Studies 6 (2): 40. https://doi.org/10.3390/ijfs6020040.

Ocampo, L., and K. Yamagishi. 2020. Modeling the lockdown relaxation protocols of the Philippine government in response to the COVID-19 pandemic: An intuitionistic fuzzy DEMATEL analysis. Socio-Economic Planning Sciences. https://doi.org/10.1016/j. seps.2020.100911.

Park, B., J. Park, and J. Chae. 2019. Non-interest income and bank performance during the financial crisis. Applied Economics Letters 26 (20): 1683-1688. https://doi.org/10.1080/13504851.2019. 1591592.

Peng, K., and G. Tzeng. 2013. A hybrid dynamic MADM model for problem-improvement in economics and business. Technological and Economic Development of Economy 19 (4): 638-660.

Phoon, K., and F. Koh. 2018. Robo-advisors and wealth management. The Journal of Alternative Investments 20 (3): 79-94. https://doi. org/10.3905/jai.2018.20.3.079.

Qarnain, S. S., S. Muthuvel and S. Bathrinath. 2020. Analyzing factors necessitating conservation of energy in residential buildings of Indian subcontinent: A DEMATEL approach. Materials Today: Proceedings. doi.org/https://doi.org/10.1016/j.matpr.2020.02.039

Qu, G.B., T.Y. Zhao, B.W. Zhu, G.H. Tzeng, and S.L. Huang. 2019. Use of a modified DANP-mV model to improve quality of life in rural residents: The Empirical Case of Xingshisi Village, China. International Journal of Environmental Research and Public Health 16 (1): 153.

Santacruz, L. 2018. Wealth management and financial advisory services in the Asia-pacific region. The Journal of Wealth Management Winter 21 (3): 95-115. https://doi.org/10.3905/jwm.2018.1. 066.

Schroder, D. 2013. Asset allocation in private wealth management: Theory versus practice. Journal of Asset Management 14 (3): 162-181. https://doi.org/10.1057/jam.2013.14.

Semko, R. 2019. Machine learning for robo-advisors: Testing for neurons specialization. Investment Management \& Financial Innovations 16 (4): 205-214. https://doi.org/10.21511/imfi.16(4).2019. 18.

Shaverdi, M., M. Akbari, and S. Fallah Tafti. 2011. Combining fuzzy MCDM with BSC approach in performance evaluation of Iranian private banking sector. Advances in Fuzzy Systems 2011: 1-12. https://doi.org/10.1155/2011/148712.

Stankevičienè, J., and E. Mencaitè. 2012. The evaluation of bank performance using a multicriteria decision making model: A case study on Lithuanian commercial banks. Technological and Economic Development of Economy 18 (1): 189-205. https://doi.org/ $10.3846 / 20294913.2012 .668373$.
Stewart, J., C. O’Halloran, P. Harrigan, J.A. Spencer, J.R. Barton, and S.J. Singleton. 1999. Identifying appropriate tasks for the preregistration year: Modified Delphi technique. BMJ 319 (7204): 224-229. https://doi.org/10.1136/bmj.319.7204.224.

Tadic, D., A. Aleksic, P. Mimovic, H. Puskaric, and M. Misita. 2018. A model for evaluation of customer satisfaction with banking service quality in an uncertain environment. Total Quality Management \& Business Excellence 29 (11-12): 1342-1361. https://doi.org/10. 1080/14783363.2016.1257905.

Taiwan Centers for Disease Control (CDC). 2020. Reported cases, https://www.cdc.gov.tw/En

Ting, H. 2017. Factors affecting wealth management services: From investors' and advisors' perspectives. The Journal of Wealth Management 20 (1): 17-29. https://doi.org/10.3905/jwm.2017.20.1. 017.

Torbacki, W., and K. Kijewska. 2019. Identifying key performance indicators to be used in logistics 4.0 and industry 4.0 for the needs of sustainable municipal logistics by means of the DEMATEL method. Transportation Research Procedia 39: 534-543. https:// doi.org/10.1016/j.trpro.2019.06.055.

Tzeng, G., G. Tzeng, C. Huang, and C. Huang. 2012. Combined DEMATEL technique with hybrid MCDM methods for creating the aspired intelligent global manufacturing \& logistics systems. Annals of Operations Research 197 (1): 159-190. https://doi.org/10.1007/s10479-010-0829-4.

Ugolini, S. 2018. The origins of Swiss wealth management? Genevan private banking, 1800-1840. Financial History Review 25 (2): 161-182. https://doi.org/10.1017/s096856501700021x.

Van der Cruijsen, C., and M. Diepstraten. 2017. Banking products: You can take them with you, so why don't you? Journal of Financial Services Research 52 (1-2): 123-154. https://doi.org/ 10.1007/s10693-017-0276-3.

Vanini, P. (2020) Asset Management, https://ssrn.com/abstract= 2710123 or http://dx.doi.org/https://doi.org/10.2139/ssrn.27101 23. Accessed 9 Nov 2020.

Verhoef, P.C., and B. Donkers. 2001. Predicting customer potential value an application in the insurance industry. Decision Support Systems 32 (2): 189-199. https://doi.org/10.1016/S01679236(01)00110-5.

Vozková, K. 2018. Determinants of bank fee income in the EU banking industry: Does market concentration matter? Prague Economic Papers 27 (1): 3-20.

Wealth Magazine, 2020. Wealth Management Award. https://www. wealth.com.tw/home/articles/14901. Accessed 10 Nov 2020.

Wu, C., C. Lin, and P. Tsai. 2010. Evaluating business performance of wealth management banks. European Journal of Operational Research 207 (2): 971-979.

Wu, C.R., C.T. Lin, and P.H. Tsai. 2011. Financial service sector performance measurement model: AHP sensitivity analysis and balanced scorecard approach. The Service Industries Journal 31 (5): 695-711. https://doi.org/10.1080/02642060902852908.

Yeh, C. 2017. Using a hybrid model to evaluate development strategies for digital content. Technological and Economic Development of Economy 23 (6): 795-809.

Yeh, Y.P. 2015. Corporate social responsibility and service innovation on customer loyalty: An empirical investigation in wealth management services. International Journal of Bank Marketing 33 (6): 823-839. https://doi.org/10.1108/IJBM-09-2014-0130.

Yin, W., and K. Matthews. 2018. Why do firms switch banks? Evidence from China. Emerging Markets Finance and Trade 54 (9): 2040-2052. https://doi.org/10.1080/1540496X.2017.1343141.

Zhang, L., X. Sun, and H. Xue. 2019. Identifying critical risks in sponge city PPP projects using DEMATEL method: A case study of China. Journal of Cleaner Production 226: 949-958. https://doi.org/10.1016/j.jclepro.2019.04.067. 
Zhao, T., K. Matthews, and V. Murinde. 2013. Cross-selling, switching costs and imperfect competition in British banks. Journal of Banking and Finance 37 (12): 5452-5462. https://doi.org/10. 1016/j.jbankfin.2013.03.008.

Publisher's Note Springer Nature remains neutral with regard to jurisdictional claims in published maps and institutional affiliations.

Arthur J. Lin obtained his Ph.D. from International Management, University of Paris 1 Pantheon-Sorbonne. He is currently an associate professor at Graduate Institute of International Business, National Taipei University. He teaches financial service marketing, management of financial institution, and international business. He has published numerous papers on the topic of international management and shipping finance.

Hai-Yen Chang is a professor at Banking and Finance, Chinese Culture University. She teaches international financial management and financial statement analysis. Her research area includes corporate finance, financial markets, and financial institution performance.
Sun-Weng Huang is a Ph.D. candidate supervised by both professor Gwo-Hshiung Tzeng and James Liou. He studies industrial engineering, and management and urban planning. His research mainly applies the multiple-criteria decision-making (MCDM) method. He has published many papers using different techniques in the MCDM approach.

Gwo-Hshiung Tzeng is a renowned professor at National Taipei University. He obtained his Ph.D. in Management Science from Osaka University. He received the award of "Highly Cited Research" in 2018. $\mathrm{He}$ is currently the Editor-in-Chief for International Journal of Operations Research. His research areas include technological management, energy, environment, transportation systems/investment, logistics, location selection, urban planning, tourism, electronic commerce, and global supply chains. He has applied a wide range of research methods, including statistics, multivariate analysis, networks, routing and scheduling, multiple-criteria decision making, fuzzy theory, and hierarchical structure analysis. 